\title{
Cross-hemispheric transport of central African biomass burning pollutants: implications for downwind ozone production
}

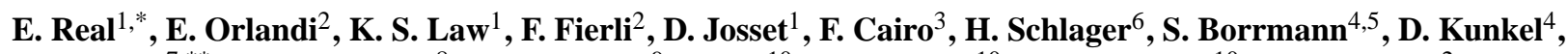 \\ C. M. Volk ${ }^{7, * *}$, J. B. McQuaid ${ }^{8}$, D. J. Stewart ${ }^{9}$, J. Lee ${ }^{10}$, A. C. Lewis ${ }^{10}$, J. R. Hopkins ${ }^{10}$, F. Ravegnani ${ }^{2}$, A. Ulanovski ${ }^{11}$, \\ and C. Liousse ${ }^{12}$ \\ ${ }^{1}$ UPMC Univ. Paris 06, Univ. Versailles St-Quentin, CNRS/INSU, UMR 8190 LATMOS-IPSL, Paris, France \\ ${ }^{2}$ Institute for Atmospheric Science and Climate, ISAC-CNR, Italy \\ ${ }^{3}$ Istituto di Scienze dell' Atmosfera e del Clima, Roma, Italy \\ ${ }^{4}$ Max Planck Institute for Chemistry, Particle Chemistry Department, Germany \\ ${ }^{5}$ Institute for Atmospheric Physics, Johannes Gutenberg Univ., Mainz, Germany \\ ${ }^{6}$ Deutsches Zentrum für Luft- und Raumfahrt (DLR), Oberpfaffenhofen, Institut für Physik der Atmosphäre, \\ 82230 Wessling, Germany \\ ${ }^{7}$ Institute for Atmospheric and Environmental Sciences, J. W. Goethe-Univ., Frankfurt, Germany \\ ${ }^{8}$ Institute for Climate and Atmospheric Science School of Earth and Environment, University of Leeds, UK \\ ${ }^{9}$ Department of Chemistry, Univ. of Reading, Reading, UK \\ ${ }^{10}$ National Centre for Atmospheric Science Department of Chemistry, Univ. of York, York, UK \\ ${ }^{11} \mathrm{CAO}$, Dolgoprudny, Russia \\ ${ }^{12}$ Laboratoire d'Aérologie, Univ. de Toulouse, France \\ * now at: CEREA, ENPC/EDF, 20 rue Alfred Nobel 77455 - Champs sur Marne, France \\ ** now at: Department of Physics, Univ. of Wuppertal, Germany
}

Received: 4 May 2009 - Published in Atmos. Chem. Phys. Discuss.: 20 August 2009

Revised: 4 March 2010 - Accepted: 10 March 2010 - Published: 30 March 2010

\begin{abstract}
Pollutant plumes with enhanced concentrations of trace gases and aerosols were observed over the southern coast of West Africa during August 2006 as part of the AMMA wet season field campaign. Plumes were observed both in the mid and upper troposphere. In this study we examined the origin of these pollutant plumes, and their potential to photochemically produce ozone $\left(\mathrm{O}_{3}\right)$ downwind over the Atlantic Ocean. Their possible contribution to the Atlantic $\mathrm{O}_{3}$ maximum is also discussed. Runs using the BOLAM mesoscale model including biomass burning carbon monoxide (CO) tracers were used to confirm an origin from central African biomass burning fires. The plumes measured in the mid troposphere (MT) had significantly higher pollutant concentrations over West Africa compared to the upper tropospheric (UT) plume. The mesoscale model
\end{abstract}

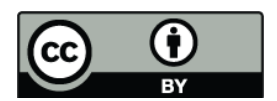

Correspondence to: E. Real (elsa.real@aero.jussieu.fr) reproduces these differences and the two different pathways for the plumes at different altitudes: transport to the northeast of the fire region, moist convective uplift and transport to West Africa for the upper tropospheric plume versus north-west transport over the Gulf of Guinea for the mid-tropospheric plume. Lower concentrations in the upper troposphere are mainly due to enhanced mixing during upward transport. Model simulations suggest that MT and UT plumes are 16 and 14 days old respectively when measured over West Africa. The ratio of tracer concentrations at $600 \mathrm{hPa}$ and $250 \mathrm{hPa}$ was estimated for 14-15 August in the region of the observed plumes and compares well with the same ratio derived from observed carbon dioxide $\left(\mathrm{CO}_{2}\right)$ enhancements in both plumes. It is estimated that, for the period 1-15 August, the ratio of Biomass Burning (BB) tracer concentration transported in the UT to the ones transported in the MT is 0.6 over West Africa and the equatorial South Atlantic.

Published by Copernicus Publications on behalf of the European Geosciences Union. 
Runs using a photochemical trajectory model, CiTTyCAT, initialized with the observations, were used to estimate in-situ net photochemical $\mathrm{O}_{3}$ production rates in these plumes during transport downwind of West Africa. The mid-troposphere plume spreads over altitude between 1.5 and $6 \mathrm{~km}$ over the Atlantic Ocean. Even though the plume was old, it was still very photochemically active (mean net $\mathrm{O}_{3}$ production rates over 10 days of $2.6 \mathrm{ppbv} /$ day and up to 7 ppbv/day during the first days) above $3 \mathrm{~km}$ especially during the first few days of transport westward. It is also shown that the impact of high aerosol loads in the MT plume on photolysis rates serves to delay the peak in modelled $\mathrm{O}_{3}$ concentrations. These results suggest that a significant fraction of enhanced $\mathrm{O}_{3}$ in mid-troposphere over the Atlantic comes from BB sources during the summer monsoon period. According to simulated occurrence of such transport, BB may be the main source for $\mathrm{O}_{3}$ enhancement in the equatorial south Atlantic MT, at least in August 2006. The upper tropospheric plume was also still photochemically active, although mean net $\mathrm{O}_{3}$ production rates were slower ( $1.3 \mathrm{ppbv} /$ day). The results suggest that, whilst the transport of BB pollutants to the UT is variable (as shown by the mesoscale model simulations), pollution from biomass burning can make an important contribution to additional photochemical production of $\mathrm{O}_{3}$ in addition to other important sources such as nitrogen oxides $\left(\mathrm{NO}_{\mathrm{x}}\right)$ from lightning.

\section{Introduction}

Biomass burning produces large quantities of pollutants which can be transported many thousands of kilometres downwind. This includes trace gases such as $\mathrm{CO}_{2}$, and precursors of $\mathrm{O}_{3}$ as well as aerosols which can also have an important impact on radiative forcing. Production of $\mathrm{O}_{3}$ downwind from source regions also influences the global oxidizing capacity through the formation of the $\mathrm{OH}$ radical, and thus the lifetime of greenhouse gases such as methane. Africa is the continent emitting the largest quantity of biomass burning (BB) emissions with a strong inter-hemispheric transition between West Africa in boreal winter to central and southern Africa in boreal summer (Crutzen and Andreae, 1990) following the location of the dry season in each hemisphere. $\mathrm{O}_{3}$ production in African fires has been studied by Mauzerall et al. (1998). Using a box model they analysed measurements taken during several days over South and central Africa in a BB plume. They found that $\mathrm{O}_{3}$ was produced in the $\mathrm{BB}$ plume only during the first 3 days after emission, followed by net $\mathrm{O}_{3}$ destruction. They also found that due to plume dilution, $\mathrm{O}_{3}$ concentrations in the plumes increased only during the first $24 \mathrm{~h}$. Chatfield et al. (1996) also simulated $\mathrm{O}_{3}$ production in BB plumes transported over the South Atlantic and estimated a slow $0.5-1 \mathrm{ppbv} /$ day decrease in $\mathrm{O}_{3}$. In contrast, Thompson et al. (1996a) in a study based on measurements taken over continent but also over the Atlantic estimated $\mathrm{O}_{3}$ production rates over the Atlantic of 1-4 ppbv/day attributed to BB plumes. Jacob et al. (1996) also estimated the $\mathrm{O}_{3}$ budget over the Atlantic based on Atlantic measurements and found slow net $\mathrm{O}_{3}$ production above $4 \mathrm{~km}$. Therefore, previous BB simulations studies (not based on measurements or based on measurements close to the emission) seem to fail to reproduce positive $\mathrm{O}_{3}$ production observed in $\mathrm{BB}$ plumes over the Atlantic, far from source emissions.

One important feature of African tropospheric $\mathrm{O}_{3}$ is the so-called maximum $\mathrm{O}_{3}$ pattern (Weller et al., 1996; Thompson et al., 1996b; Jenkins and Ryu, 2004a): high concentrations over the tropical Atlantic are enhanced throughout the year. During boreal summer (wet season), the $\mathrm{O}_{3}$ maximum is generally located close to the West African coast around $-10^{\circ} \mathrm{S}$ but $\mathrm{O}_{3}$ enhancements can extend further north (up to $5^{\circ} \mathrm{N}$ ) and south $\left(-20^{\circ} \mathrm{S}\right)$. Layers with enhanced $\mathrm{O}_{3}$ have been observed in ozone sonde data in the mid and upper troposphere over the Atlantic Ocean (Thompson et al., 1996a; Jenkins et al., 2008) and over West Africa (Thouret et al., 2009) during the summer monsoon period.

Two processes have been suggested to explain this $\mathrm{O}_{3}$ maximum: 1) photochemical production of $\mathrm{O}_{3}$ following $\mathrm{NO}_{\mathrm{x}}$ (nitrogen oxyde $(\mathrm{NO})+$ dioxyde $\left(\mathrm{NO}_{2}\right)$ ) release by lightning $\left(\mathrm{LiNO}_{\mathrm{x}}\right)$ associated with deep convection has been proposed to explain enhanced $\mathrm{O}_{3}$ observed above $700 \mathrm{hPa}$ (Jacob et al., 1996; Jenkins and Ryu, 2004b); 2) production of $\mathrm{O}_{3}$ in $\mathrm{BB}$ plumes. The relative importance of these 2 processes is still not well quantified. Whereas some studies suggest a comparable importance, Sauvage et al. (2007a) suggested that annual $\mathrm{O}_{3}$ production from $\mathrm{BB}$ sources only represents $1 / 4$ of that from $\mathrm{LiNO}_{\mathrm{x}}$ emissions.

As mentioned earlier, in Africa, BB regions are located south of the equator during boreal summer. Direct westward transport to the ocean of $\mathrm{BB}$ air masses could explain $\mathrm{O}_{3}$ enhancements between -10 to $-20^{\circ} \mathrm{S}$ but in order to contribute to enhanced $\mathrm{O}_{3}$ at more northerly latitudes than $-10^{\circ} \mathrm{S}, \mathrm{BB}$ emissions must be transported to equatorial latitudes. This hypothesis is supported by several recent studies (Sauvage et al., 2005; Mari et al., 2008; Jenkins et al., 2008). Sauvage et al. (2005) first suggested that $\mathrm{O}_{3}$ transport from central Africa to West Africa in the MT could explain $30 \%$ of enhancements observed in ozone sonde data. In a later analysis of ozonesonde data collected at Cotonou (Benin) on the southern coast of West Africa, Thouret et al. (2009) showed that these mid-troposphere enhancements are more frequent in August than in June or September and exhibit a strong inter-annual variability. During these years they estimated that during June-July-August (JJA), 41\% of sampled layers exhibited mid-troposphere $\mathrm{O}_{3}$ enhancements. They also showed that during JJA the vertical layer contributing the most to tropospheric $\mathrm{O}_{3}$ columns is the $500-250 \mathrm{hPa}$ layer. However, during August, layers below $500 \mathrm{hPa}$ accounted for half the total column. Mari et al. (2008) also investigated the variability in the transport of $\mathrm{BB}$ emissions 
from central Africa to the gulf of Guinea (West Africa) and the Atlantic Ocean in the mid-troposphere during July and August 2006 and suggested that it is driven by variations in the southern branch of the African Easterly Jet. During periods when this jet is less active, BB emissions can be trapped over the continent and injected into the upper troposphere by deep convection. However, the relative importance of midlevel versus upper level transport of BB emissions was not studied in detail.

Whilst, pathways for the transport of BB emissions out of central Africa have been identified and related to vertical ozone sonde data or to data collected by the MOZAIC programme in the upper troposphere (Mari et al., 2008; Thouret et al., 2009; Sauvage et al., 2007b), the relative importance of mid versus upper tropospheric transport are still not well quantified. The potential of these BB air masses to produce $\mathrm{O}_{3}$ downwind of the emission region and their contribution to the $\mathrm{O}_{3}$ maximum over the southern Atlantic Ocean are also still very uncertain.

In this paper, we examine, in detail, using tracer simulations from a mesoscale model, the origin of two pollution plumes observed in the Mid Troposphere (MT) and Upper Troposphere (UT) during August 2006 over the southern coast of West Africa during the AMMA (African Monsoon Multidisciplinary Analysis) project.

Thanks to a high altitude aircraft this was the first time that trace gas and aerosol measurements were performed in the upper troposphere over West Africa. The plume observations are discussed in Sect. 2). The high levels of trace gaz emitted in fire ( $\mathrm{CO}, \mathrm{CO}_{2}$, acetonitrile) and of aerosols suggest a BB origins. Confirmation of their origins and transport pathways to West Africa are then investigated using fire $\mathrm{CO}$ tracers run in a mesoscale model (Sect. 3). The results from these simulations are used to quantify the mechanisms responsible for transporting the plumes from the Southern to the Northern Hemisphere where they were observed in the MT and UT over West Africa. In particular, we use the results to diagnose the travel times between the source region and the region where the observations were collected as well as the fraction of tracer transported into the UT compared to the MT. We also estimate, based on photochemical trajectory model simulations initialised with plume concentrations, net photochemical $\mathrm{O}_{3}$ production rates in the MT and UT central African BB plumes during transport downwind over the Atlantic (Sect. 4). The results are discussed in the context of the possible contribution of $\mathrm{BB}$ emissions to the Atlantic $\mathrm{O}_{3}$ maximum and previous studies. Conclusions are presented in Sect. 5.

\section{Observational evidence}

During August 2006, five aircraft equipped with trace gas and aerosol instrumentation made flights over West Africa as part of an AMMA special observing period with the aim to improve understanding about processes influencing atmospheric composition over this region. An overview of the main findings from this campaign is given in Reeves (2010) including details about instrument payloads and flights. Here, we focus on the analysis of plumes observed in the MT and also in the UT on 13 August 2006 when 4 aircraft flew to the Gulf of Guinea (UK BAe-146 (B-146), French Falcon-20 (FF20), DLR Falcon-20 (DF-20) and the M55-Geophysica (M55)).

First considering the MT plume(s), layers with high concentrations of $\mathrm{CO}, \mathrm{CO}_{2}$, peroxyacytyle nitrate (PAN), $\mathrm{NO}_{\mathrm{x}}$, $\mathrm{O}_{3}$, acid nitric $\left(\mathrm{HNO}_{3}\right)$ Volatile Organic Carbons (VOCs) and aerosols were sampled between 2.5 and $4.5 \mathrm{~km}$ by the B146 , and $3 \mathrm{~h}$ later by the DF-20 below $5.5 \mathrm{~km}(500 \mathrm{hPa})$ over southern West Africa and the Gulf of Guinea (see Figs. 1, 2 and Table 1). For example, the DF-20 measured up to $450 \mathrm{ppbv} \mathrm{CO}, 130 \mathrm{ppbv}_{3}$ and more than $8 \mathrm{ppbv} \mathrm{NO}_{\mathrm{y}}$ $\left(\mathrm{NO}+\mathrm{NO}_{2}+\mathrm{PAN}+\mathrm{HNO}_{3}\right.$ etc.) (see Fig. 2). The $\mathrm{NO}: \mathrm{NO}_{\mathrm{y}}$ was rather low (0.04) indicating that significant photochemical processing had taken place and therefore discounting local anthropogenic emissions as the origin. The FF-20, which flew to the same region, also sampled air masses with elevated $\mathrm{CO}$ and $\mathrm{O}_{3}$ at around $8 \mathrm{~km}$ at $6^{\circ} \mathrm{N}$ on the same day with an origin over the Gulf of Guinea according to Ancellet et al. (2009). The B-146 observed rather similar CO and $\mathrm{O}_{3}$ concentrations especially in the upper part of their plume sampling suggesting that both aircraft sampled the same polluted air mass. The B-146 also sampled high concentration of PAN (greater than $800 \mathrm{pptv}$ ) together with high acetonitrile concentration, a strong indicator of BB emissions (Reeves, 2010). The DF-20 plume also had high $\mathrm{CO}_{2}$ concentrations up to $390 \mathrm{ppmv}$ (mean value of $387 \mathrm{ppmv}$ ). These observations strongly suggest the presence of a large BB plume over the Gulf of Guinea extending between about 3 and $6 \mathrm{~km}$ : denoted the MT plume in the rest of the paper. Interestingly, data collected on the 4 August 2006, when a similar flight was made over this region, also showed evidence for $\mathrm{BB}$ plumes with elevated trace gas and aerosol concentrations, including $\mathrm{CO}_{2}$ up to $379 \mathrm{ppmv}$ Andres-Hernandez et al. (2009).

The high altitude M55-Geophysica (M55) aircraft also flew on this day (see Cairo et al., 2010 for a discussion about the aircraft campaign and payload). Interestingly, a plume was observed by the M55 during a dive over the Gulf of Guinea down to $200 \mathrm{hPa}(12 \mathrm{~km})$ : denoted the UT plume in the rest of the paper. Observations showed elevated concentrations of trace gases (see Fig. 3) and aerosols. Measurements of $\mathrm{CO}_{2}$ in the dive (around $380 \mathrm{ppmv}$ ) were higher than measured at similar altitudes during the rest of the campaign (see Fig. 3b). Higher $\mathrm{CO}_{2}$ concentrations in the Tropical Tropopause transition Layer (TTL) are usually attributed to uplift of mid-latitude air masses several months earlier when surface concentrations are higher (e.g. Park et al., 2007). However, $\mathrm{CO}_{2}$ concentrations are also elevated in $\mathrm{BB}$ air masses (as in the MT BB plume observed by the DF-20 

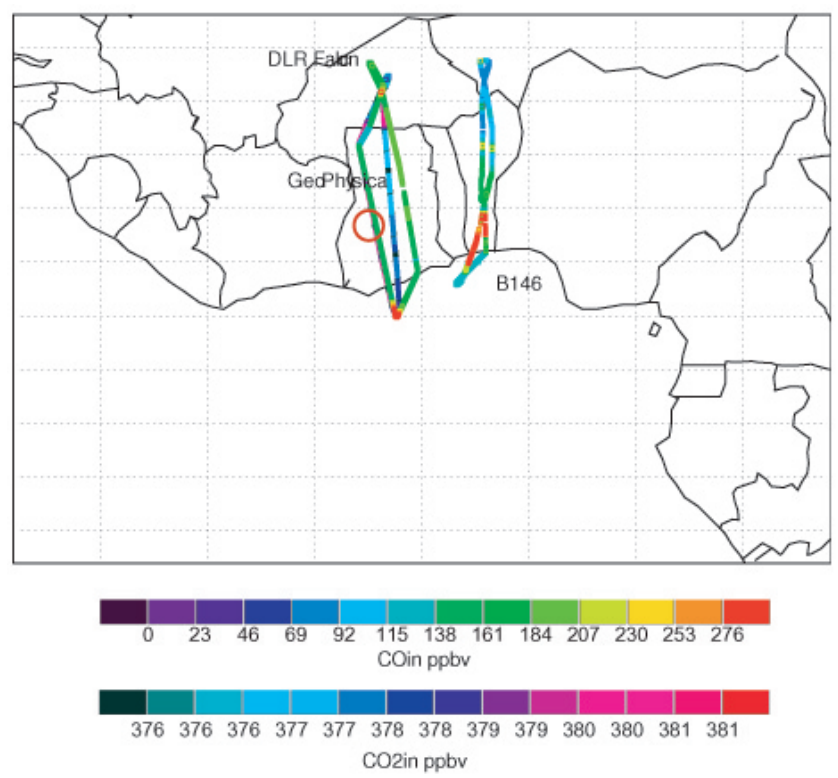

(a) horizontal map

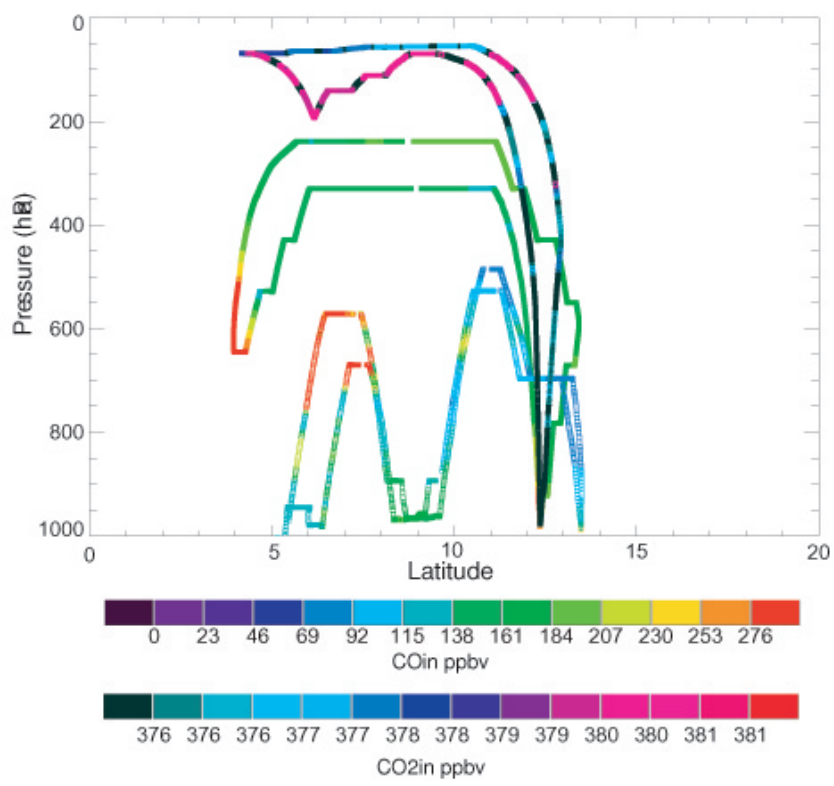

(b) altitude-latitudinal cross-sections

Fig. 1. Flight path for 13 August 2006 flight. Colour scales represent the $\mathrm{CO}$ concentrations from the DF-20 and the B-146 and $\mathrm{CO}_{2}$ concentrations for the M55 aircraft. See text for details.

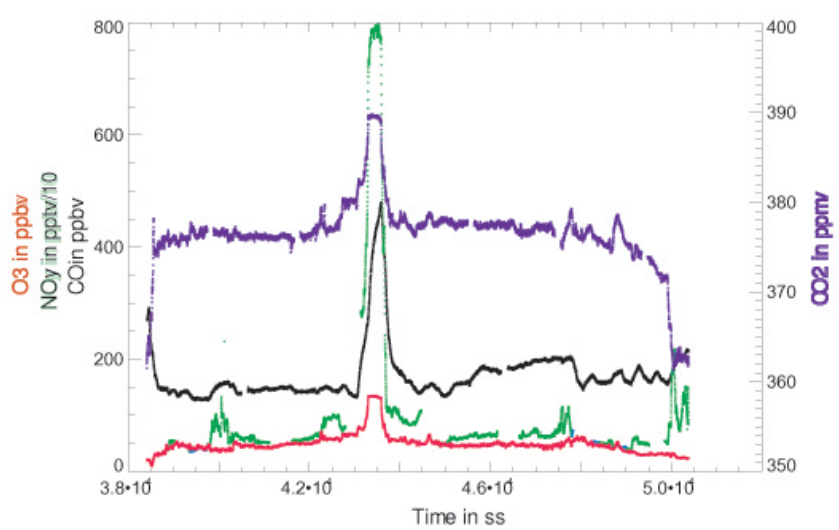

(a) DLR Falcon

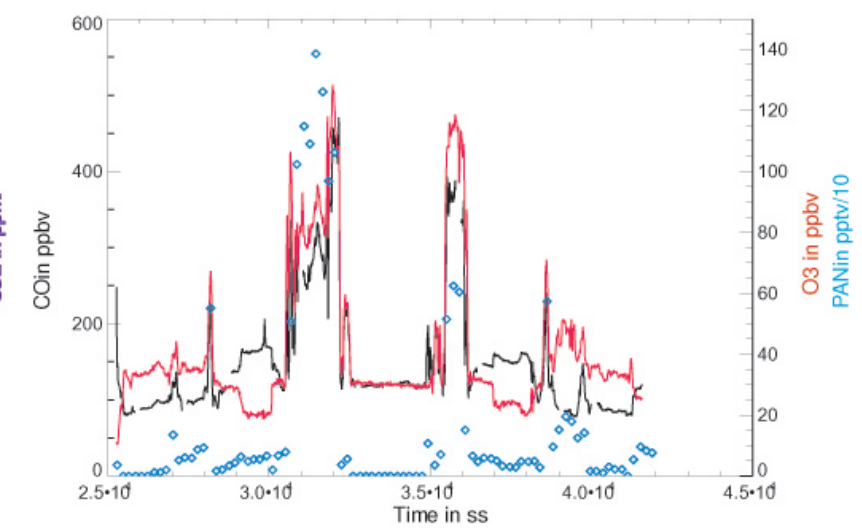

(b) Bae-146

Fig. 2. Measurements taken on 13 August 2006 by the DLR Falcon aircraft (left hand) and the Bae-146 (right hand).

on the same day). $\mathrm{O}_{3}$ concentrations were around $60 \mathrm{ppbv}$ which is in the upper range of measurements collected at these altitudes during the rest of the M55 campaign (Law, 2010) and also compared to average tropical profiles reported in Fueglistaler et al. (2009) which show a minimum in the upper troposphere at these altitudes attributed to uplift of $\mathrm{O}_{3}$ poor air. $\mathrm{NO}$ and $\mathrm{NO}_{\mathrm{y}}$ were also higher during the plume sampling with up to 300 pptv $\mathrm{NO}$ and 1 ppbv $\mathrm{NO}_{\mathrm{y}}$. Whilst, these $\mathrm{NO}_{\mathrm{y}}$ concentrations are not very elevated (Voigt et al., 2008) the fact that the NO: $\mathrm{NO}_{\mathrm{y}}$ ratio is around 0.3 suggests that this air mass may also have been influenced by more recent $\mathrm{LiNO}_{\mathrm{x}}$ emissions associated with deep convection. This point is discussed further in Sect. 4.2.
The M55 plume also showed slightly elevated concentrations (up to 10000 molecules per milligram of air) of finemode aerosol. This is in the upper range of measurements collected at these altitudes during the rest of the campaign (Borrmann et al., 2009). The fact that particle concentrations for sizes less than $6 \mathrm{~nm}$ and less than $14 \mathrm{~nm}$ are very similar indicates that no new nucleation had recently taken place. Analysis of other flights (4 and 11 August 2006) when measurements of the non-volatile fraction are also available show that a significant fraction (up to 60\%) of particles in the lower TTL were non-volatile and contained soot or nonvolatile organic aerosols suggesting injection from a surface source such as BB emissions could be influencing upper 
Table 1. Mean concentrations and standard deviations (in brackets) measured in the MT plume by the Bae-146 and the DLR Falcon aircrafts. No standard deviations are given for hydrocarbons as they result from one sampling measurement. Concentrations used to initialised the box model calculation are given in the third column. In case both aircrafts measured the same species, the average is calculated. $\mathrm{HNO}_{3}$ is calculated as the sum: $\left(\mathrm{NO}_{y}-\mathrm{PAN}-\mathrm{NO}_{2}-\mathrm{NO}\right)$. Background concentrations are taken from Jacob et al. (1996) (4-8 km).

\begin{tabular}{|c|c|c|c|c|}
\hline & Bae-146 & DLR Falcon & Initialisation & background concentrations \\
\hline $\mathrm{CO}$ (ppbv) & $385(80)$ & $373(80)$ & 379 & 103 \\
\hline $\mathrm{O}_{3}$ (ppbv) & $108(18)$ & $116(22)$ & 112 & 69 \\
\hline NO (pptv) & $244(100)$ & $196(43)$ & 220 & 29 \\
\hline $\mathrm{NO}_{2}$ (pptv) & & $300(102)$ & 300 & 50 \\
\hline PAN (pptv) & $1200(450)$ & & 1200 & 294 \\
\hline $\mathrm{HNO}_{3}$ (pptv) & & & 6000 & 130 \\
\hline $\mathrm{NO}_{\mathrm{y}}$ & & $7720(2000)$ & & \\
\hline $\mathrm{C}_{2} \mathrm{H}_{4}$ (pptv) & 18 & & 18 & \\
\hline $\mathrm{C}_{2} \mathrm{H}_{6}$ (pptv) & 2760 & & 2760 & 630 \\
\hline $\mathrm{C}_{2} \mathrm{H}_{2}$ (pptv) & 1400 & & 1400 & 130 \\
\hline $\mathrm{C}_{3} \mathrm{H}_{6}$ (pptv) & 4 & & 4 & 4 \\
\hline $\mathrm{C}_{4} \mathrm{H}_{1} \mathrm{O}$ (pptv) & 30 & & 30 & \\
\hline $\mathrm{C}_{5} \mathrm{H}_{1} 2$ (pptv) & 4 & & 4 & \\
\hline $\mathrm{C}_{6} \mathrm{H}_{6}(\mathrm{pptv})$ & 326 & & 326 & 21 \\
\hline $\mathrm{C}_{7} \mathrm{H}_{8}$ (pptv) & 10 & & 10 & 2 \\
\hline Formaldehyde (pptv) & 1110 & & 1110 & 40 \\
\hline Acetaldehyde (pptv) & 1030 & & 1030 & 320 \\
\hline Acetone (pptv) & 2010 & & 2010 & 593 \\
\hline $\mathrm{CO}_{2}(\mathrm{ppmv})$ & & $387(3)$ & & 376 \\
\hline
\end{tabular}

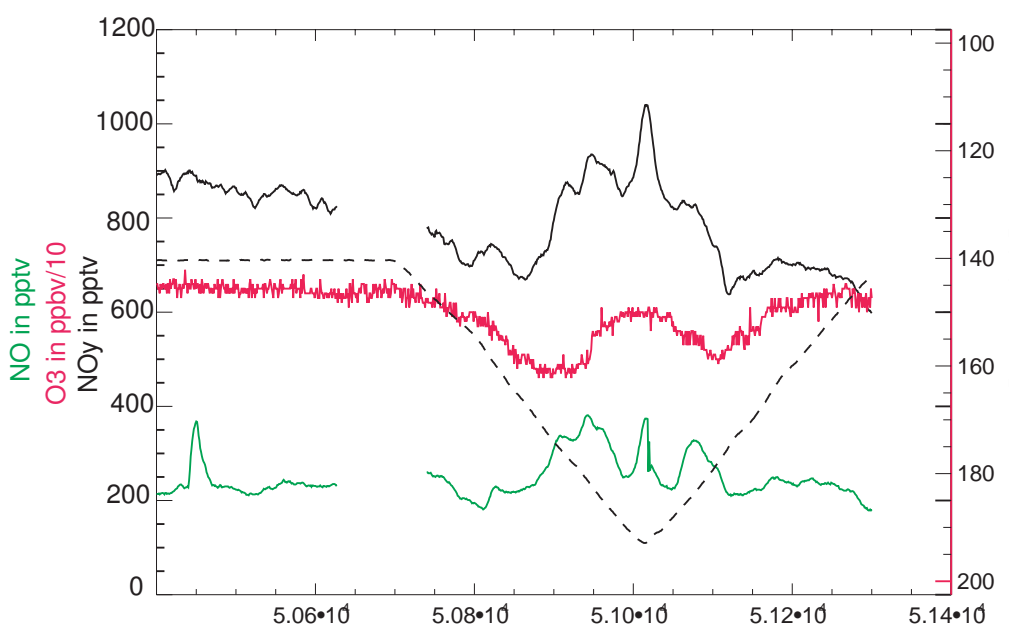

(a) $\mathrm{NO}, \mathrm{NO}_{\mathrm{y}}, \mathrm{O}_{3}$

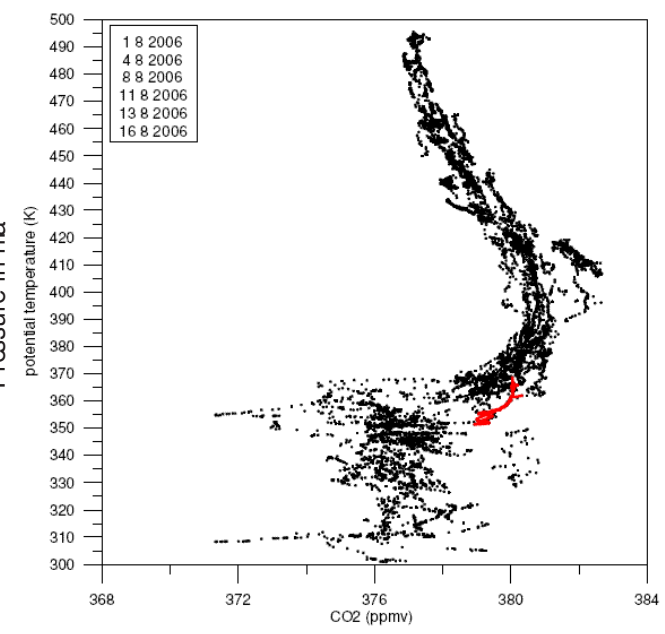

(b) $\mathrm{CO}_{2}$

Fig. 3. Right hand figure: Measurements of $\mathrm{NO}, \mathrm{NO}_{\mathrm{y}}$ and $\mathrm{O}_{3}$ taken on 13 August 2006 by the GeoPhysica. Left hand figure: Measurements of $\mathrm{CO}_{2}$ taken during the whole campaign, $\mathrm{CO}_{2}$ measured during the dive on the 13 August is highlighted in red.

tropospheric aerosol composition over West Africa (Borrmann et al., 2009). Finally, whilst CO was not measured on this day by the M55, the DF-20 and the FF-20 (Ancellet et al., 2009) also sampled plumes with elevated $\mathrm{CO}$ at around $11 \mathrm{~km}$ over the southern coast of West Africa (see Fig. 2). Analysis of MOZAIC data collected between 1 to $16 \mathrm{Au}-$ gust 2006 in the upper troposphere also shows the existence of several plumes between the Equator and $5^{\circ} \mathrm{N}$ with $\mathrm{CO}$ concentrations above $150 \mathrm{ppbv}$ and, in one case as high as $230 \mathrm{ppbv}$ in the upper troposphere $(240 \mathrm{hPa})$ (J. P. Cammas., personal communication, 2009) Examination of air mass origins in the TTL $(350-380 \mathrm{~K}, 250$ to $50 \mathrm{hPa})$ for this campaign using ensembles of back trajectories from both the M55 flight paths and the TTL region over West Africa showed that 10 
to $15 \%$ of the measured air masses up to $150 \mathrm{hPa}$ probably originate from central Africa during the period 13 to $16 \mathrm{Au}$ gust.

In summary, it appears that the MT plume(s) has the characteristics of a $\mathrm{BB}$ origin with high concentrations of trace gases (including $\mathrm{BB}$ tracers) and aerosols. Considering the UT plume, high $\mathrm{CO}_{2}$ concentrations indicate a $\mathrm{BB}$ origin but the air mass may also have been influenced by $\mathrm{LiNO}_{\mathrm{x}}$. In the next section we examine the transport mechanisms responsible for transporting BB plumes originating from central Africa to the MT and UT over West Africa. The possible $\mathrm{LiNO}_{\mathrm{x}}$ influence is discussed further in Sect. 4.

\section{Cross-hemispheric transport of BB plumes: mechanisms and travel times}

\subsection{Meteorological situation}

The circulation over West Africa during the summer monsoon is dominated by the northward migration of the InterTropical Front denoting the convergence between southwesterly monsoon winds and north-easterly dry Harmattan winds, and associated westward propagation of organised mesoscale convective systems linked to the position and strength of the African Easterly Jet (AEJ). The 2006 monsoon was characterised by slightly higher convective activity (stronger AEJ) than average and an intertropical convergence zone at $10^{\circ} \mathrm{N}$ in August. The upper level tropical easterly jet, positioned at around $5^{\circ} \mathrm{N}$ was also stronger in August 2006 with a slight north-east/south-west tilt compared to its mean position. For further discussion about the meteorological situation during the wet season in 2006 compared to other years see Janicot et al. (2008).

As discussed in the Introduction, Sauvage et al. (2006) attributed mid-tropospheric $\mathrm{O}_{3}$ enhancements over the southern coast of West Africa to direct transport of BB plumes in the mid-troposphere during the summer monsoon. This transport pathway is associated with a convergence zone at $5 \mathrm{~S}$ over central Africa followed by transport by southeasterly trade winds over the Gulf of Guinea. Mari et al. (2008) further investigated cross-hemispheric transport of BB pollution during July and August 2006 using of fire tracer simulations in the FLEXPART model. They examined the relationship between the intrusion of BB emissions into West Africa, and the strength of a mid-level jet over central Africa. This jet previously identified by Burpee (1972); Nicholson and Grist (2003), and denoted African Easterly Jet south (AEJ-S) in Mari et al. (2008) had a mean position around $5^{\circ} \mathrm{S}$ and $700 \mathrm{hPa}$ in 2006. Mari et al. (2008) found that during so-called AEJ-S active phases (25 July to 2 August 2006; 10 to 31 August 2006), this jet extended westwards over the ocean thus driving lower tropospheric intrusions of BB plumes over the Gulf of Guinea. During break phases ( 3 to 9 August 2006) such transport is inhibited and BB pollutants remain trapped over the central African continent. Whilst Mari et al. (2008) suggested that BB plumes can also be uplifted by deep convection into the upper troposphere followed by westward transport by the tropical easterly jet they did not examine this second transport pathway in detail. Here, we use a mesoscale model, BOLAM (Bologna Limited Area Model) Buzzi and Foschini (2000), to quantify the relative fractions of BB pollutants transported in the UT compared to the MT and to investigate how long it took the pollutants to arrive over southern West Africa where the measurements were taken. We also use the model results to estimate dilution rates for the UT plume in the chemical trajectory model calculations.

\subsection{Model description and simulation set up}

BOLAM is a limited-area, primitive equation, terrainfollowing coordinate, hydrostatic meteorological model. A detailed description of the dynamics and numerical schemes of the model can be found in Malguzzi et al. (2006). The main prognostic variables are the wind components $(u$ and $v$ ), the potential temperature, the surface pressure, and the specific humidity. The water cycle for stratiform precipitation is described by means of five additional prognostic variables: cloud ice, cloud water, rain, snow, graupel The horizontal discretization is based on a (staggered) Arakawa C grid, in geographical coordinates (latitude-longitude). Deep convection is parametrized using the Kain-Fritsch convection scheme, recently updated on the basis of the revision proposed by Kain (2004).

The model simulations discussed here were run over the domain shown in Fig. 4 with a horizontal resolution of $0.26^{\circ} \times 0.26^{\circ}$ and 38 hybrid sigma vertical levels from the ground to $10 \mathrm{hPa}$. The model was initialized using $0.5^{\circ} \times 0.5^{\circ}$ European Centre for Medium Range Weather Forecast (ECMWF) meteorological analyses at 00:00 UT on 15 July 2006 and run for 32 days until 00:00 UT on $16 \mathrm{Au}-$ gust 2006. ECMWF analyses were also used to update the lateral boundary conditions every $6 \mathrm{~h}$. Time-varying CO-like BB tracer emissions were introduced into the model for the duration of the run. Daily fire emissions were interpolated from 5-day running-mean averaged emissions taken from the AMMA African BB inventory compiled by Liousse (2010), specifically for 2006. Separate tracers were injected daily for $24 \mathrm{~h}$ up to an altitude of $1 \mathrm{~km}$ and then transported for the rest of the simulation, in order to follow the fate of $\mathrm{BB}$ plumes emitted on each day of the run. Figure 5 shows the BB CO emissions averaged between 15 July and 15 August 2006 together with the ECMWF wind field at $750 \mathrm{hPa}$ averaged over the same period. The two transport pathways for the BB plumes in lower troposphere to the north-east and north-west can be seen. 

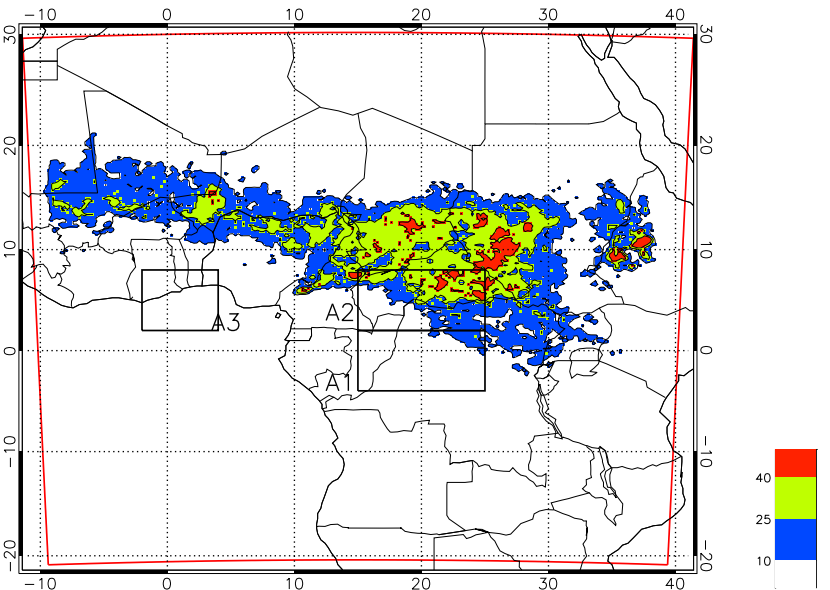

Fig. 4. Percentage of cloud cover for model-derived cloud top brightness temperature less than $230 \mathrm{~K}$. Cloud Percentage is relative to the period 15 July-15 August. Black squares indicate the averaging area used in Fig. 7. Red box indicates the BOLAM model domain.

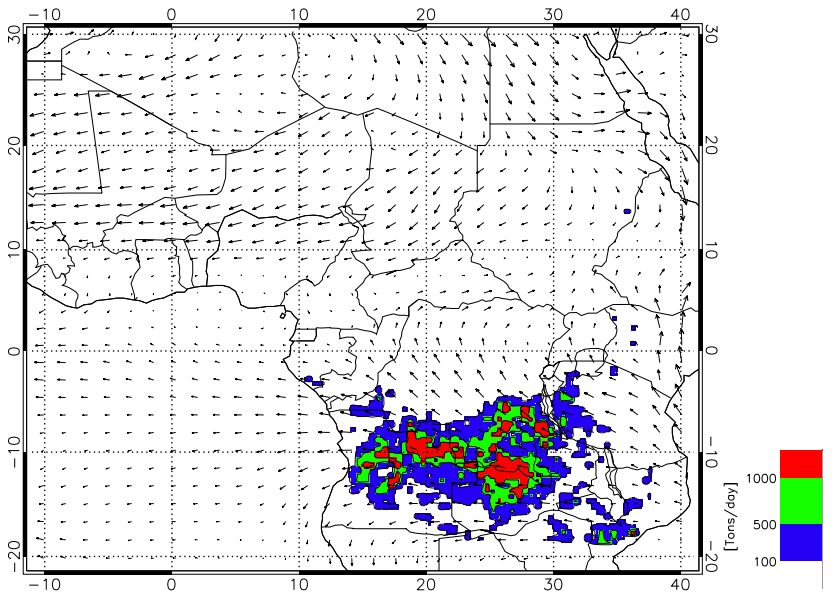

Fig. 5. CO flux averaged between 15 July and 15 August. Thin arrows are ECMWF wind field averaged between 15 July and $15 \mathrm{Au}-$ gust at $750 \mathrm{hPa}$.

\subsection{BB tracer results}

In this section the model capacity to reproduce convective activity was first evaluated. Then the model time distribution of BB tracers was studied (from 15 July to 15 August), showing the episodic nature of transport in equatorial regions both in the UT and the MT. Different pathways for UT and MT plumes were simulated and the ratio of tracers transported in the UT to those transported in the MT was evaluated and compared with measurements. Finally the plumes age over West Africa were evaluated using modelled tracers.

The performance of the BOLAM model in reproducing convective activity was evaluated using cloud top brightness temperatures derived from the 10.8 micrometer channel of the SEVIRI radiometer, on-board of Meteosat Second

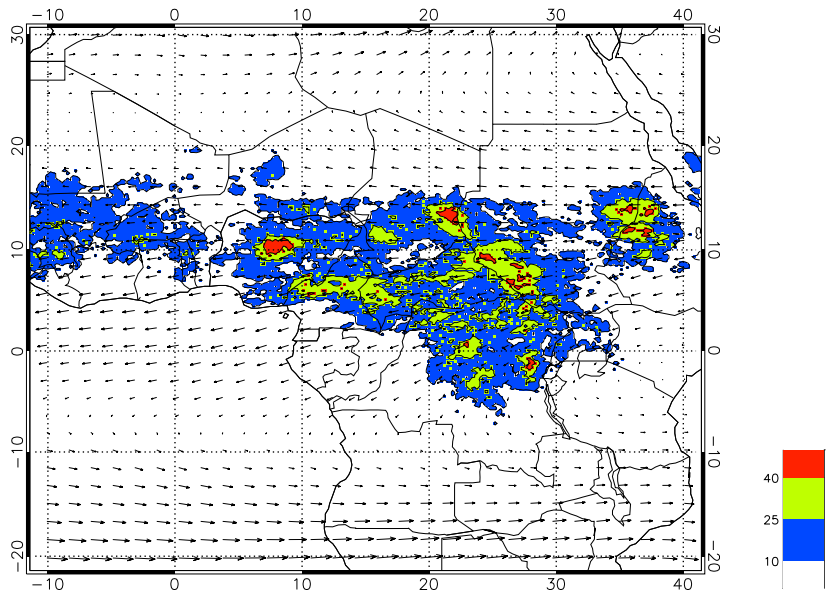

Fig. 6. Percentage of cloud cover for cloud top brightness temperature less than $230 \mathrm{~K}$, evaluated from MSG-SEVIRI radiometer. Percentage is relative to the period 15 July-15 August. Thin arrows are ECMWF wind field at $250 \mathrm{hPa}$ averaged over the same period.

Generation satellite. These values were compared with cloud top brightness temperatures calculated using the RTTOV-8 (Proceedings of the Fourteenth International TOVS Study Conference Conference; Beijing, 2005) radiative transfer model and BOLAM water vapour, temperature and hydrometeor profiles. The percentage cloud cover with cloud top temperatures less than $230 \mathrm{~K}$ together with ECMWF winds at $250 \mathrm{hPa}$ are shown in Fig. 6. The figure shows the regions with greater convective activity and the tropical easterly jet that transports the air masses uplifted by deep convection toward West Africa. Figure 4 shows the percentage of cloud cover calculated from the BOLAM model for the same period. The model reproduces reasonably well the structure and intensity of convective activity. The meridional position of the intertropical convergence zone in West Africa is displaced northward in the model by about 5 degrees while its northern extent in Sudan and Chad is well simulated. However, BOLAM simulates less convective activity in Democratic Republic of Congo, Cameroon and Nigeria and overestimates convection in Central African Republic, Sudan and Chad.

Figure 7 shows the time evolution of tracer profiles averaged over three different areas highlighted in Fig. 4. In these and subsequent figures we only display $\mathrm{CO}$ tracers which are 20 days old or younger based on estimates of the chemical of CO lifetime in the lower tropical troposphere (Mauzerall et al., 1998). Area A1 is located just to the north of the emission region and area A2 is located further north. Note that results are not shown below $900 \mathrm{hPa}$ over these regions due to the presence of mountains. Area A3 is located in the region where the aircraft observed the polluted plumes on 13 August. Significant tracer arrives in A1 and A2 in the mid-troposphere starting on 17 July in the region A1, and later from 22 July in A2. There is significant variability in the modelled tracer transport which depends on the 

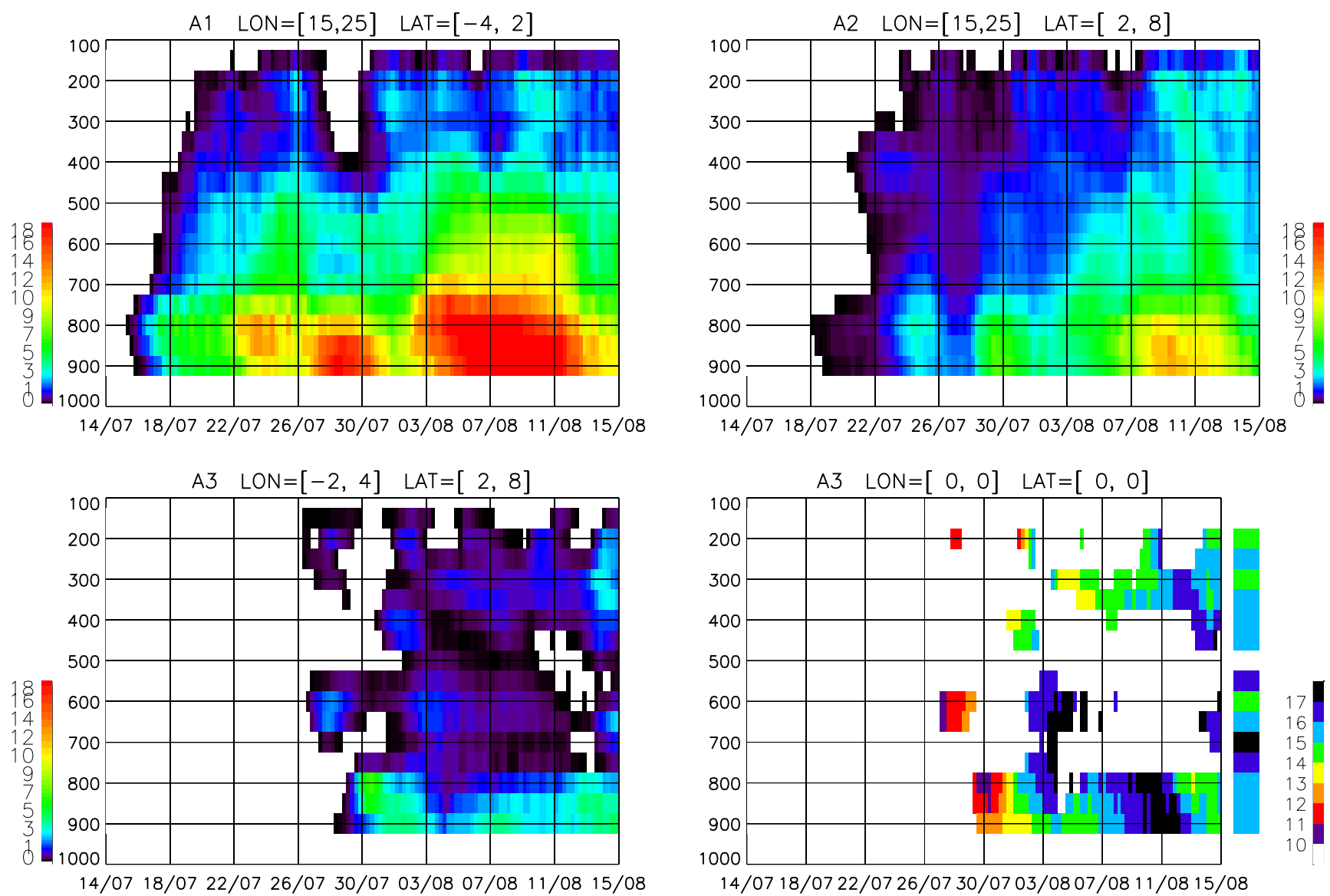

Fig. 7. Time-pressure plot of tracer concentration (in tracer units) averaged over areas A1, A2 and A3 (top left, top right and bottom left, respectively). Time-pressure plot of tracer travel time for area A3 (bottom right). Travel time is given in days.

daily position of fires and the intensity of the low level winds. Three episodes of high BB tracer concentrations are visible in A1 in the lower troposphere. The one between 3-11 August 2006 corresponds reasonably well with the break phase of the AEJ-S described by Mari et al. (2008) when pollutants build up over the continent, even if the model has higher concentrations and simulated tracers for longer over this region than simulated by Mari et al. (2008). Injection into the UT is also episodic and depends on the position of convective activity relative to the availability of pollutants (tracer) at lower altitudes. There is a clear increase in MT and UT tracer after the 5 August, especially in A2 where the convection is located (see Fig. 6). At mid-levels (around $650 \mathrm{hPa}$ ) over West Africa enhancements in $\mathrm{A} 3$ tracer concentration are seen between 27-29 July, 2-5 August and after 14 August. In the UT tracer arrives, albeit with low values, around 1 August with a more intense peak after the 14 August. This later enhancement corresponds well with the plume location measured by the M55 even but the modelled plume arrives 1 day later. The plume is quite dispersed in the vertical. This may be realistic since the DF-20 may have also sampled a BB plume in the UT around $11 \mathrm{~km}$ (see Sect. 2).
Examination of tracer concentrations at different altitudes shows that the MT and UT BB tracer follow different pathways. During the break phase (e.g. 3-11 August in the model) what becomes UT tracer is uplifted by wet convection in the area around the equator spanning longitudes between $15^{\circ}$ and $25^{\circ} \mathrm{E}$, and in the area around $5^{\circ} \mathrm{N} 22^{\circ} \mathrm{E}$. The MT tracer is transported into the mid-troposphere south of the equator between $10^{\circ}$ and $23^{\circ} \mathrm{S}$, where wet convection is absent according to the model and less intense according to the satellite cloud measurements (see Figs. 6 and 4). Then, it is transported vertically by both dry convection and the baroclinic cell previously described by Sauvage et al. (2005).

The ratio of tracer in the UT versus MT $\left(\frac{\text { TraceruT }}{\text { TracerMT }_{M}}\right)$ can be estimated using observed $\mathrm{CO}_{2}$ enhancements above background in both plumes and compared with results from the BOLAM model. Enhancements of about $11 \mathrm{ppmv}$ and 4 ppmv are measured for the MT and UT plumes, respectively (see Figs. 2 and 3) giving a measured ratio of around 0.36 . Taking into account the $24 \mathrm{~h}$ delay in higher modelled concentrations reaching the measurement location, we use model results on 14 and 15 August to estimate the modelled ratio of UT $(200 \mathrm{hPa})$ to MT $(650 \mathrm{hPa})$ tracer. The area 
selected to evaluate the ratio was chosen to contain almost all the plumes and spans from $10^{\circ} \mathrm{S}$ to $15^{\circ} \mathrm{N}$ and $10^{\circ} \mathrm{W}$ to $10^{\circ} \mathrm{E}$. The UT:MT ratio varies between 0.3 and 0.6 between 14-15 August, with an average of 0.42 over this period which is similar to that derived from the $\mathrm{CO}_{2}$ measurements. Values inferred from Mari et al. (2008) suggest a lower fraction transported into the upper troposphere $(0.05-0.2)$ based on study using FLEXPART driven with ECMWF winds over the region encompassing $30 \mathrm{~W}-10 \mathrm{E}$. The UT:MT ratio was also calculated for a longer period from 1-15 August. To take into account the variability of the vertical position and thickness of the plumes, two pressure layers were used: $800 \mathrm{hPa}-$ $500 \mathrm{hPa}$ and $500 \mathrm{hPa}-150 \mathrm{hPa}$. $500 \mathrm{hPa}$ was chosen since the model shows a discontinuity in tracer concentration at this altitude which can be interpreted as the transition between the UT and MT transport pathways. The ratio over this period varies between 0.25 and 1 , giving 0.6 on average. Therefore, according to the model, a significant fraction (higher than previously reported) of BB emissions can be transported into the UT but this fraction remains lower that those transported in the MT. These differences in tracer concentrations are due to 1) the fact that wet convection is needed to inject tracer in the UT and 2) higher mixing of tracer when transported in the UT. This more intense mixing is due to both uplift by deep convection and dispersion by wind fields. In fact, entrainment and detrainment of ambient air within the vertical column is taken into account in the model convective parametrization leading to tracer mixing with cleaner air masses. Furthermore, dispersion occurs in the outflow region due to divergent winds that form at the top of the uplift column.

Since we emitted one tracer per day the results can also be used to estimate the time since emission as a function of altitude. This time since emission is obtained from a mean age of the tracers on each days, weighted by their concentrations. Results over A3 are shown in Fig. 7 averaged over the whole simulation period. The time for the tracers to arrive over West Africa with maximum modelled concentrations in the UT (14 August) at $200 \mathrm{hPa}$ is 14 to 15 days whereas the MT plume takes between 16 to 17 days. An estimate of the time needed by pollutants to travel between areas A1/A2 and area $\mathrm{A} 3$ was also estimated by dividing the longitudinal distance between the centres of areas A1 and A2 $\left(20^{\circ} \mathrm{E}\right)$ and the centre of area $\mathrm{A} 3\left(1^{\circ} \mathrm{E}\right)$ by the zonal wind speed averaged between 11-15 August and averaged over the region encompassing areas $\mathrm{A} 1, \mathrm{~A} 2$ and $\mathrm{A} 3\left(4^{\circ} \mathrm{S}\right.$ and $8^{\circ} \mathrm{N}$; $2^{\circ} \mathrm{W}$ and $25^{\circ} \mathrm{E}$ ). We derive a transit time of 4-5 days for the MT plume and 1-2 days for the UT plume. This is faster than the 8 days reported by Sauvage et al. (2005). However, that study was based on a climatological (1997-2003) analysis of MOZAIC profile data, and could be due to differences in wind speeds between different years. Our results suggest that this transport can be much faster in certain cases.

In summary, the modelled tracer results support the hypothesis of direct mid-troposphere transport of BB plumes from central Africa to the southern coast of West Africa. These MT plumes contain high pollutants concentrations due to the time spent in the vicinity of the emission regions. We also show that BB pollutants transported further north can be uplifted into the UT by wet convection, and transported westward to the measurement region over West Africa. These plumes exhibit lower concentrations probably due to enhanced mixing. For the 1-15 August period a ratio between tracers concentration in the UT and the MT of 0.6 was evaluated over a region encompassing West Africa and the eastern part of equatorial south Atlantic.

\section{Ozone production in plumes transported downwind of West Africa}

In this section, we address the question about whether these $\mathrm{BB}$ plumes continue to produce $\mathrm{O}_{3}$ downwind from where the measurements were taken, i.e. over the equatorial South Atlantic. A photochemical model, CiTTyCAT (including 90 chemical species, see Evans et al., 2000; Real et al., 2007 for details) was initialized with mean concentrations taken from available measurements and run forwards for 10 days along selected air masses trajectories. The trajectories were calculated from the location of the BB measurements (MT and UT) using the FLEXTRA model (Stohl et al., 1995) run with ECMWF wind fields (see Fig. 8). The MT plume was transported over the southern Atlantic Ocean before reaching the south American east coast. The UT plume was also transported over ocean but it recirculated back to the central African coast. Simulations of the chemical fate of both plumes were carried out including diagnosis of photochemistry versus mixing/dilition of the plume with background air, and the impact of aerosols on photolysis rates for the MT plume.

\subsection{Chemical fate of the MT plume}

\subsubsection{Model set-up}

On 13 August 2006, the B-146 sampled the lower part of the plume, followed $3 \mathrm{~h}$ later by the DF-20 sampled its upper part. Since these plumes have very similar origin measurements can be combined to provide mean values to initialize the model MT plume simulations (see Table 1). Forward trajectories initialized in the plume show similar directions but different altitudes at the end between 1.5 and $6.5 \mathrm{~km}$. One trajectory was chosen to conduct the main simulations (black one in Fig. 8) and a sensitivity test regarding the choice of trajectory is presented in Sect. 4.1.3.

For the main simulations, three runs were conducted: chemistry-only (Run-CHEM), chemistry plus impact of aerosols on photolysis rates (Run-AER) and chemistry plus aerosols plus mixing/dilution of the plume (Run-MIX). To simulate aerosol impacts on photolysis rates, the FAST-J scheme (Wild et al., 2000) was used (see Real et al., 2007 for 


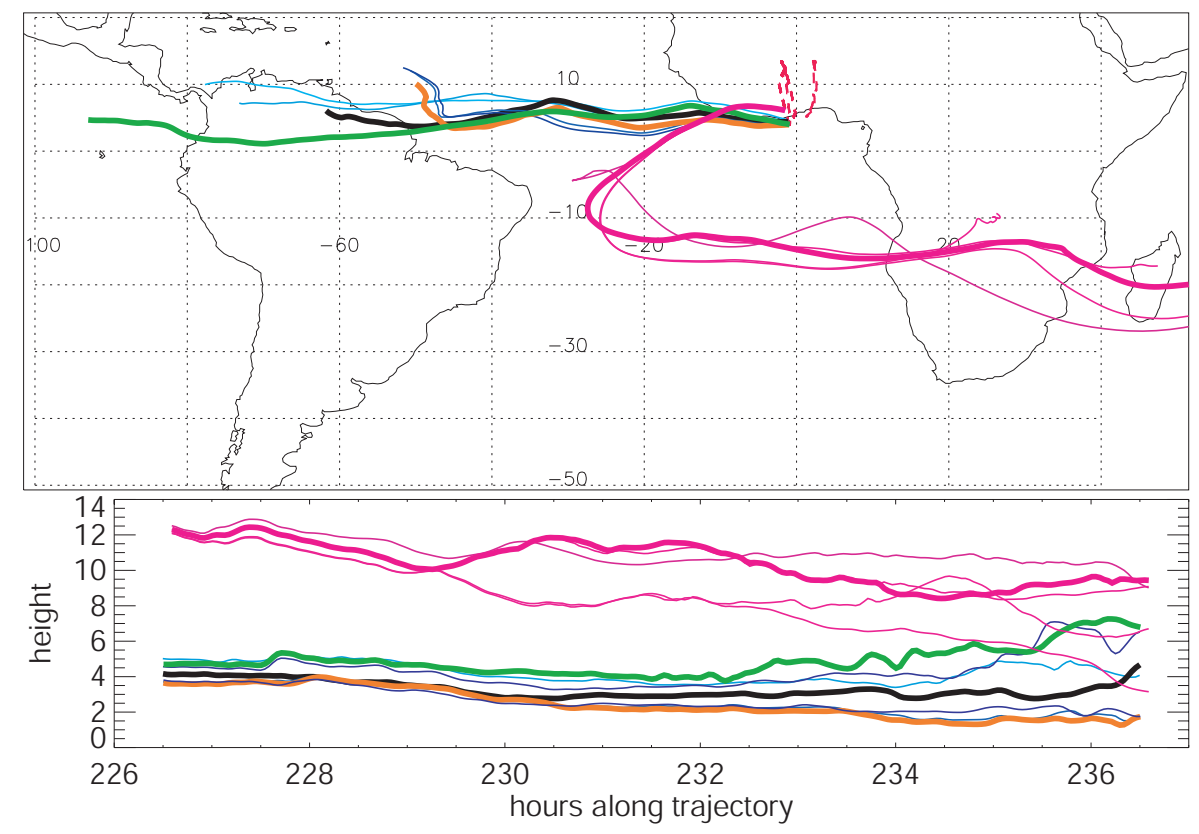

Fig. 8. 10 days simulated forward trajectories initialised from the MT plume and the UT plume. 3 MT trajectories were chosen to performe MT run (green, black and orange bold lines) and one trajectory for the UT run (pink bold line). Flight tracks of the DLR Falcon, the BAe-146 and the GeoPhysica aircrafts are represented as red dashed lines.

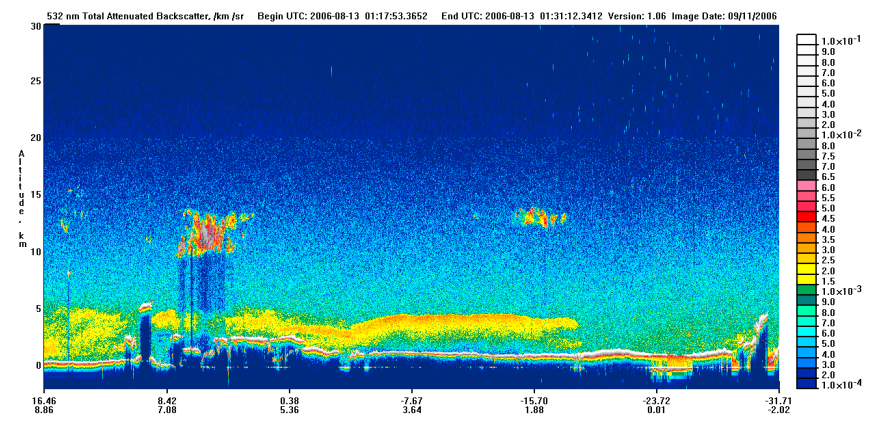

(a) 13 August

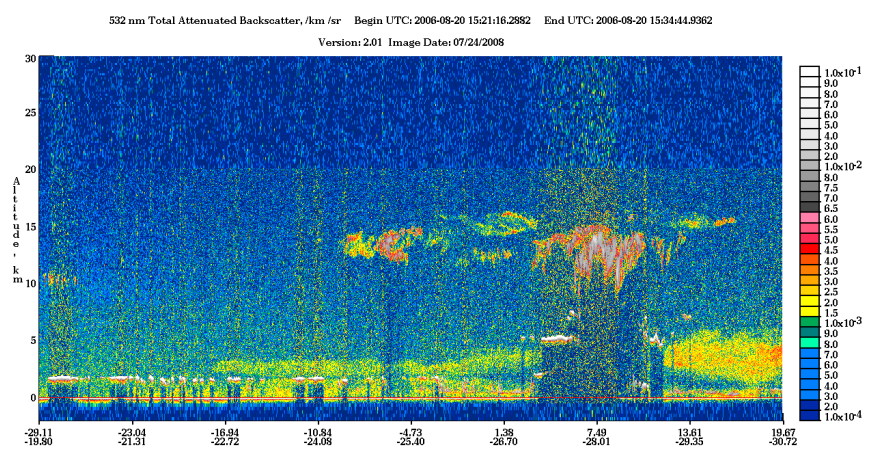

(b) 20 August

Fig. 9. CALIPSO images during the paths of 13 August over the Gulf of Guinea (right hand) and over the SAO on 20 August (left hand). Plumes with high concentrations of aerosols are visible between 2 and $5 \mathrm{~km}$.

details). This scheme requires information about the aerosol optical depth (AOD) of the aerosol layer and aerosol optical properties. Refractive indices $(\mathrm{Ri}=1.54-0.078)$ and aerosol size distributions were taken from measurements made in aged BB plumes from a South African fire (Haywood et al., 2003), and used to calculate optical properties using a Mie code (Mishchenko et al., 1999). The $550 \mathrm{~nm}$ AOD was retrieved from MODIS satellite measurements (Tanre et al., 1997; Remer et al., 2005) which passed over the Gulf of Guinea on 13 August, and over south Atlantic 7 days later. The collocated CALIPSO lidar data (Winker et al., 2003) clearly show that the main AOD contribution is due to the presence of an aerosol layer between 4 and $6 \mathrm{~km}$ on $13 \mathrm{Au}-$ gust, and also on 20 August albeit less intense (see Fig. 9).
MODIS Aqua aerosol level 2 products version 5 (MYD04) and CALIPSO level 1 version 2 data $(532 \mathrm{~nm}$ total attenuated backscatter) were used in this analysis. An AOD of 0.9 on 13 August and 0.3 on 20 August were estimated for the aerosol layer. Therefore, in Run-AER the AOD was allowed to decrease linearly from 0.9 during the first 7 days and then held constant at 0.3 .

The dilution of trace gas concentrations in the MT plume were simulated as an exponential decay toward background concentrations with prescribed mixing rates based on measurements as far as possible. This treatment of mixing of a plume has been used previously, and is detailed in Evans et al. (2000); Real et al. (2007). Assuming no physical changes in aerosols during transport (ECMWF analyses do 

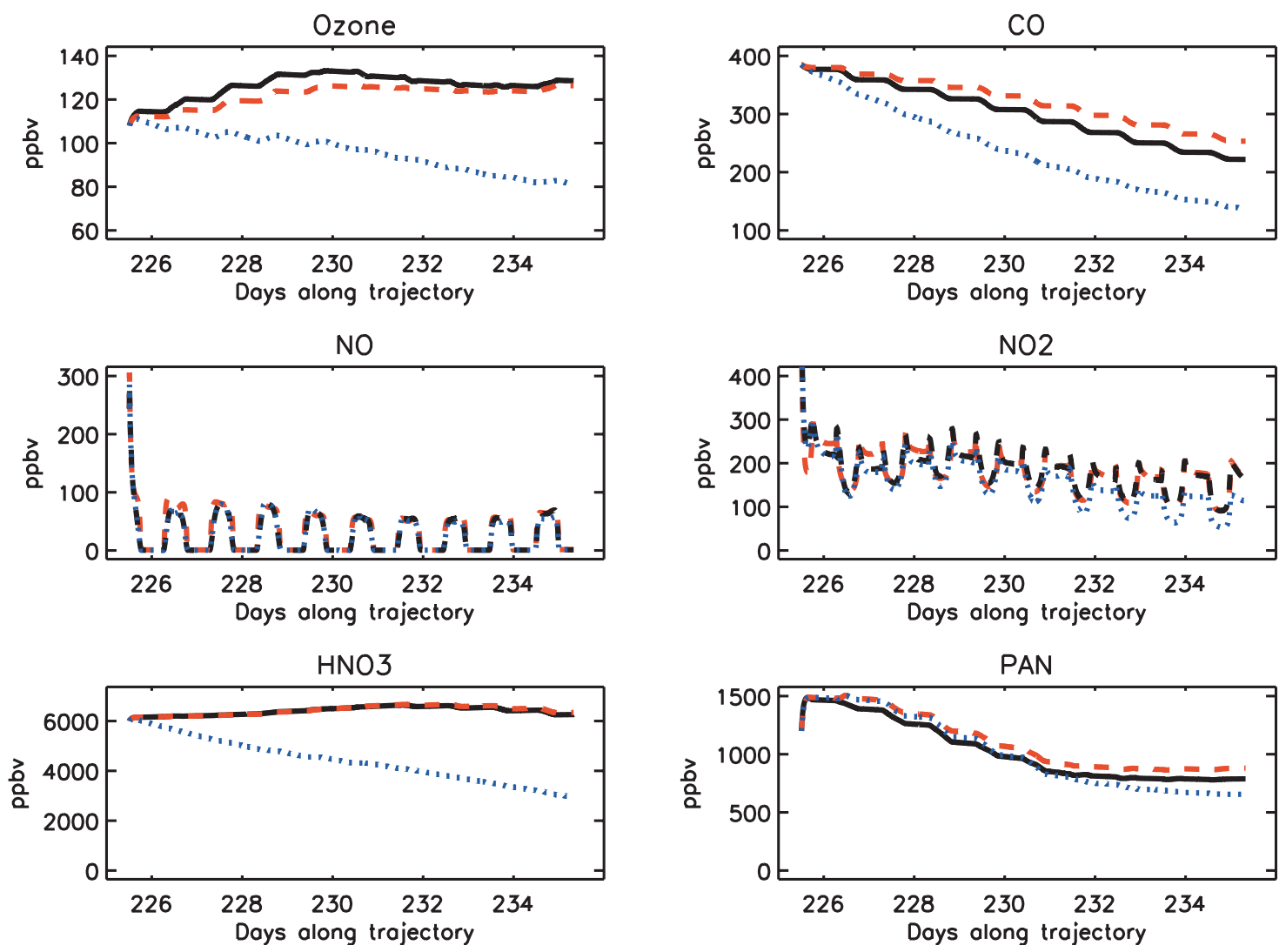

Fig. 10. Simulated concentrations in the MT plume for case RUN-CHEM (black lines), RUN-AEROSOL (red lines) and RUN-MIXING (blue lines).

not show any precipitation along the trajectory) and a zero aerosol background, observed decreases in AOD were used to estimate a mixing rate of 6.4 days. This mixing rate compares well with values estimated by Real et al. (2007) at mid-latitudes in the free troposphere under meteorological conditions dominated by large-scale advection, which is also the case for the MT plume studies here. For background concentrations, mean measurements taken between 4-8 km during the TRACE-A campaign over the southern Atlantic, and reported in Jacob et al. (1996) were used (see Table 1).

\subsubsection{Results}

Changes in simulated MT plume concentrations during 10 days are shown in Fig. 10 for Run-CHEM (black continuous line), Run-AER (red dashed line) and Run-MIX (blue dotted line). Run-AER simulates slightly lower $\mathrm{O}_{3}$ and higher CO than Run-CHEM although changes are small. Run-MIX, which represents the more realistic run, generally produces lower concentrations of all species compared to Run-AER due to mixing with cleaner air masses. Mixing has less impact on more reactive species such as $\mathrm{NO}_{\mathrm{x}}$ and also, PAN which is mainly influenced by temperature-driven decomposition.
Before describing chemistry going on in the plume, we sum-up the main processes influencing $\mathrm{O}_{3}$ concentrations in the troposphere. $\mathrm{O}_{3}$ is produced by the photolysis of $\mathrm{NO}_{2}$ and destroyed by reaction with NO. In the presence of carbonaceous species (VOC, $\mathrm{CO}$ or $\mathrm{CH}_{4}$ ) additional $\mathrm{O}_{3}$ can be formed due to the additional formation of $\mathrm{HO}_{2}$ and higher peroxy radicals. $\mathrm{O}_{3}$ can also be destroyed by photolysis in presence of water vapour or reaction with $\mathrm{OH}$ or $\mathrm{HO}_{2}$. $\mathrm{NO}_{2}$ mainly recycles with $\mathrm{NO}$ but can be stored in reservoir species such as PAN or $\mathrm{HNO}_{3}$. Thermal decomposition of PAN (under high temperatures) or photolysis of $\mathrm{HNO}_{3}$ can release $\mathrm{NO}_{2}$ back into the atmosphere leading to additional photochemical $\mathrm{O}_{3}$ production.

Net photochemical $\mathrm{O}_{3}$ production $\left(\mathrm{NPO}_{3}\right)$, given by the difference between photochemical $\mathrm{O}_{3}$ production and loss, simulated along the trajectory is shown in Fig. 11 together with $\mathrm{O}_{3}$ production and loss terms. In Run-CHEM, the plume exhibits a mean $\mathrm{NPO}_{3}$ of about $4.7 \mathrm{ppbv} /$ day during the first 4 days and slow net loss $(-0.7 \mathrm{ppbv} /$ day $)$ during the last 6 days. This translates into a mean $\mathrm{NPO}_{3}$ rate of $1.7 \mathrm{ppbv} /$ day over 10 days. Photochemical $\mathrm{O}_{3}$ production only decreases slightly over the 10 days due to a decrease in $\mathrm{NO}_{\mathrm{X}}$ that is transformed into $\mathrm{HNO}_{3}$. Concerning $\mathrm{O}_{3}$ destruction, it mainly follows water vapor content with decrease 


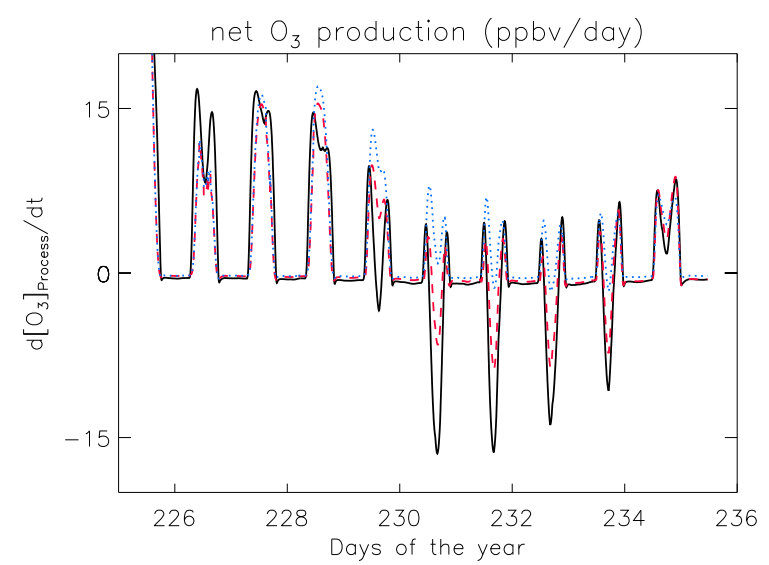

(a) $\mathrm{O}_{3}$ net production

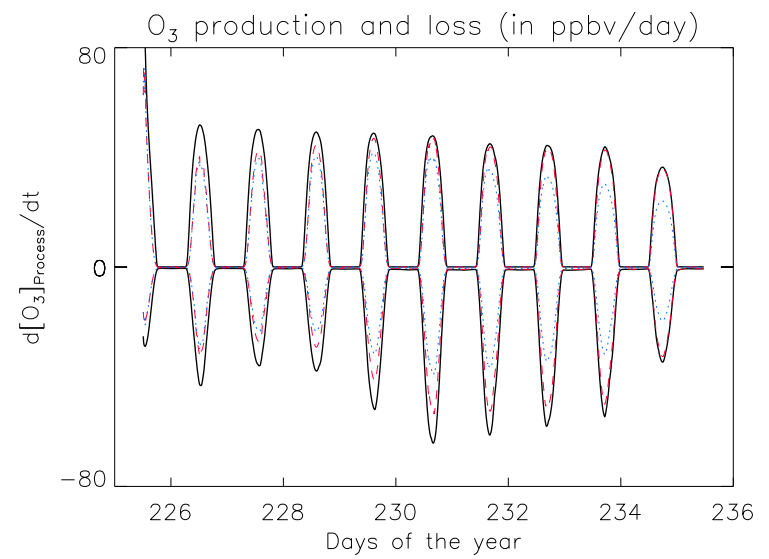

(b) $\mathrm{O}_{3}$ production and loss

Fig. 11. 10 days simulated net $\mathrm{O}_{3}$ production (left hand) and simulated production and destruction terms (right hand) in the MT plume.

during half of the simulation followed by increase. The production dominates until the 4th day of the simulation when increases in water vapour lead to additional $\mathrm{O}_{3}$ destruction. Also, due to increasing $\mathrm{O}_{3}$ concentrations, $\mathrm{O}_{3}$ loss also increases via photolysis and reaction with $\mathrm{HO}_{2}$.

Daily $\mathrm{NPO}_{3} \mathrm{~s}$ in Run-AER compared to Run-CHEM show strong differences: a $-25 \%$ reduction during the first few days when there is net $\mathrm{O}_{3}$ production, and a net increase in $\mathrm{NPO}_{3}$ in Run-AER during the last 6 days when there is net $\mathrm{O}_{3}$ loss. When averaged over 10 days, this leads to a mean $\mathrm{NPO}_{3}$ in Run-AER which is only slightly lower compared to Run-CHEM (1.6 ppbv/day or $6 \%$ reduction). Indeed, because they absorb and scatter light, aerosols have the effect of reducing the photolysis rates of both $\mathrm{NO}_{2}$ and $\mathrm{O}_{3}$, and therefore $\mathrm{O}_{3}$ production and $\mathrm{O}_{3}$ destruction respectively. As already discussed in Real et al. (2007), when an air mass is in an $\mathrm{O}_{3}$ destruction regime $\left(\mathrm{O}_{3}\right.$ loss higher than production), a similar proportional reduction of both $\mathrm{O}_{3}$ production and destruction quantitatively reduce the destruction more than the production leading to less net $\mathrm{O}_{3}$ destruction overall (see also Fig. 11). Inversely, in an $\mathrm{O}_{3}$ production regime, $\mathrm{O}_{3}$ production is reduced more than $\mathrm{O}_{3}$ loss, leading to lower $\mathrm{O}_{3}$ concentrations. One important difference between the 2 runs is that the $\mathrm{O}_{3}$ maximum appears later in the Run-AER case.

In Run-MIX the mean $\mathrm{NPO}_{3}$ is larger ( $2.6 \mathrm{ppbv} /$ day) than without mixing. In this run, mean concentrations of $\mathrm{O}_{3}$ precursors, like $\mathrm{NO}_{\mathrm{x}}$, are lower leading to a decrease in $\mathrm{O}_{3}$ production. However, $\mathrm{O}_{3}$ itself also strongly decreases due to mixing with clean air masses leading to a larger reduction in $\mathrm{O}_{3}$ destruction compared to $\mathrm{O}_{3}$ production, and therefore larger $\mathrm{NPO}_{3}$. However $\mathrm{O}_{3}$ concentration at the end of the simulation is lower than in Run-CHEM because of mixing with $\mathrm{O}_{3}$ poor air masses.

In the 3 simulations $\mathrm{O}_{3}$ production is maintained by two processes: PAN thermal decomposition during the subsidence of the plume due to increases in temperature, and $\mathrm{HNO}_{3}$ photolysis. Sensitivity runs without a) PAN decomposition and b) $\mathrm{HNO}_{3}$ photolysis show that these processes contribute almost equally to $\mathrm{NPO}_{3}$ in the plume. When both processes are removed, $\mathrm{NPO}_{3}$ is negative. This shows that in this aged plume, $\mathrm{O}_{3}$ production is not directly maintained by $\mathrm{NO}_{\mathrm{x}}$ concentrations but by $\mathrm{NO}_{2}$ from reservoir species: PAN and $\mathrm{HNO}_{3}$. PAN has already been shown to play an important role in tropospheric $\mathrm{O}_{3}$ production downwind from source regions (Heald et al., 2004). In particular, in BB plumes transported over the North Atlantic it was shown that PAN decomposition explain $80 \%$ of $\mathrm{O}_{3}$ production (Real et al., 2007). The role of $\mathrm{HNO}_{3}$ as a source of available $\mathrm{NO}_{\mathrm{x}}$ for $\mathrm{O}_{3}$ production is less well quantified with $\mathrm{HNO}_{3}$ being mainly seen as a loss for $\mathrm{NO}_{2}$. It has been shown that when $\mathrm{HNO}_{3}$ concentrations are very high ( $>15000$ pptv), $\mathrm{HNO}_{3}$ photolysis can maintain $\mathrm{O}_{3}$ production in anthropogenic plumes transported over oceans at midlatitudes (Neuman et al., 2006; Real et al., 2008). Here, $\mathrm{HNO}_{3}$ concentration are not as high, but since the MT plume is transported at equatorial latitudes, photolysis rates are higher, and the role of $\mathrm{HNO}_{3}$ as a source of $\mathrm{O}_{3}$ is more important.

\subsubsection{Sensitivity study on the trajectory used}

Trajectories simulated with FLEXTRA initialized in the plume show that during transport over the Atlantic the plume is spread over different altitudes. Main simulations were conducted over a trajectory that stayed above $4 \mathrm{~km}$. According to CALIPSO data on 20 August above the Atlantic, the plume spread between 1.5 and $5.5 \mathrm{~km}$ (also depending on the latitude). Therefore, we examine the sensitivity of the results to the choice of trajectory. The model was run along 2 additional trajectories, with same chemical initialization. The first was subject to a slow ascent up to $6 \mathrm{~km}$ (green trajectory on Fig. 8, R-HighLevel) and the second descended 

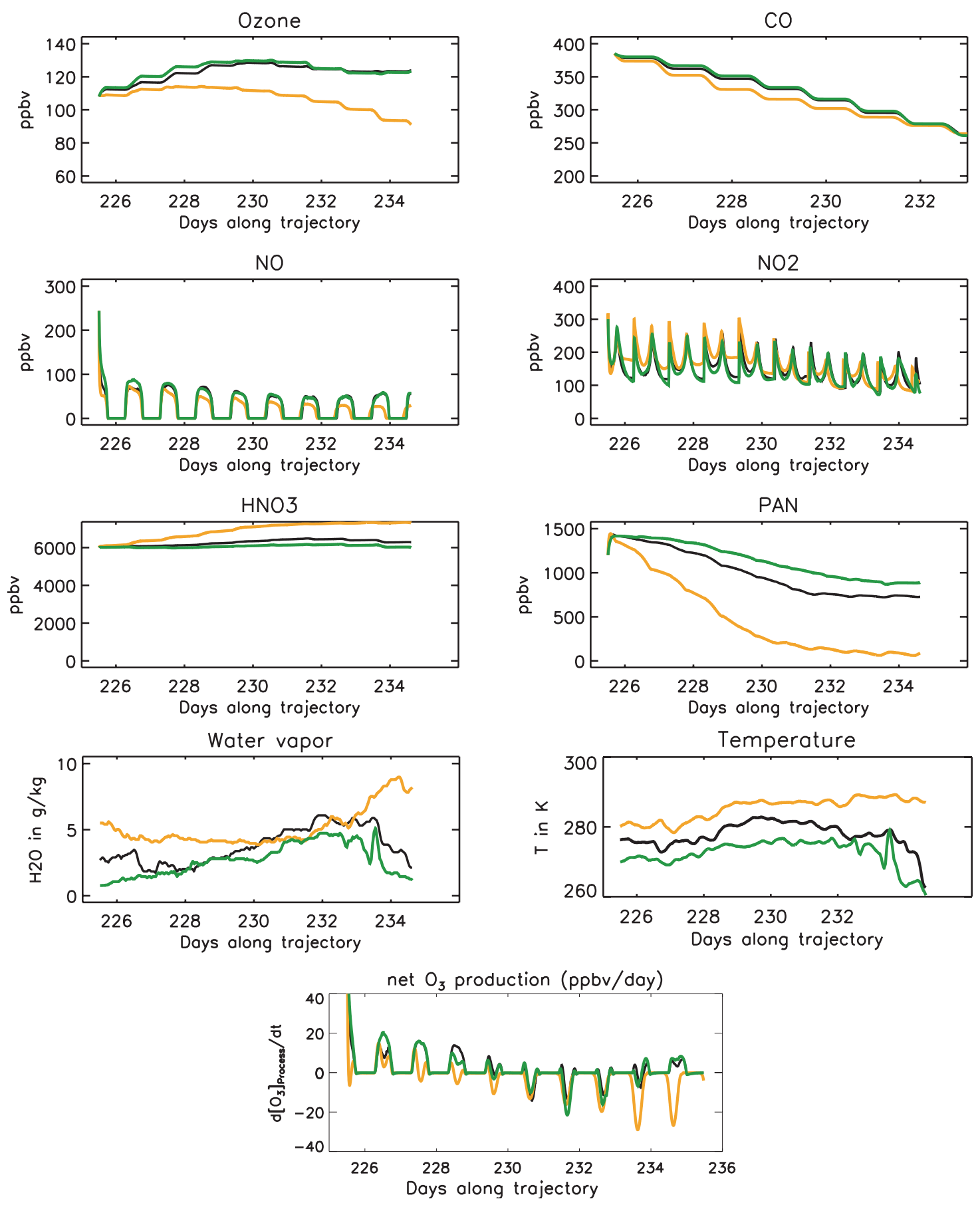

Fig. 12. Simulated concentration in the MT plume for case RUN-CHEM but for 3 different trajectories. Colours correspond to colours of the trajectories in Fig. 8: black for the reference trajectory, green for R-HighLevel and orange for R-Lowlevel. Simulated $\mathrm{NPO}_{3}$ is also shown.

below $2 \mathrm{~km}$ (orange trajectory on Fig. 8, R-LowLevel). Results are shown Fig. 12 with no dilution and no aerosol impact. Temperature and water vapour simulated over the trajectories are also shown together with the net $\mathrm{O}_{3}$ production. $\mathrm{R}$-HighLevel and the reference run show similar $\mathrm{O}_{3}$ concentrations. Temperature and water vapour are lower in the RHighLevel trajectory that was transported at higher altitudes.
Lower temperatures lead to less PAN decomposition and less $\mathrm{O}_{3}$ production but at the same time $\mathrm{O}_{3}$ destruction is lower due to less water vapour. In the case shown here, these processes compensate each other resulting in little $\mathrm{O}_{3}$ change overall. On the other hand, $\mathrm{O}_{3}$ concentrations are very different between R-LowLevel and the 2 other simulations (around $25 \mathrm{ppbv}$ after 10 days). R-LowLevel experiences 
higher temperatures and water vapour concentrations. $\mathrm{O}_{3}$ production following PAN decomposition is maintained during the first 4 days but when PAN concentrations are too low, strong $\mathrm{O}_{3}$ destruction induced by the high water vapour dominates leading to negative $\mathrm{NPO}_{3}$ overall. Mean $\mathrm{NPO}_{3}$ simulated (with no dilution or aerosol impact) is $1.7 \mathrm{ppbv} /$ day for the reference case against $1.6 \mathrm{ppbv/day}$ for R-HighLevel and $-2 \mathrm{ppbv/day}$ for R-LowLevel. When including aerosol and mixing effects (not shown), $\mathrm{NPO}_{3}$ is $2.5 \mathrm{ppbv} /$ day for $\mathrm{R}$-HighLevel and $-0.5 \mathrm{ppbv/day}$ for R-LowLevel (against $2.6 \mathrm{ppbv} / \mathrm{day}$ for the reference run). Final $\mathrm{O}_{3}$ concentrations after 10 days are $80 \mathrm{ppbv}$ (R-HighLevel) and $71 \mathrm{ppbv}$ (RLowLevel) when aerosol and mixing are included. Above the mid Atlantic $\left(-20^{\circ} \mathrm{W}\right.$ and $\left.-40^{\circ} \mathrm{W}\right)$, simulated $\mathrm{O}_{3}$ concentrations are between 80 and $100 \mathrm{ppbv}$ for trajectories above $4 \mathrm{~km}$ and $71-80 \mathrm{ppbv}$ for the lowest trajectory (not shown). This study shows that $\mathrm{NPO}_{3}$ in a plume transported over the Atlantic is very sensitive to the altitude of the transport with more $\mathrm{O}_{3}$ production in the mid-troposphere compared to the lower troposphere where $\mathrm{NPO}_{3}$ is negative.

\subsubsection{Comparison with previous studies}

The $\mathrm{O}_{3}$ concentrations and $\mathrm{NPO}_{3}$ rates presented in the previous section can be compared with $\mathrm{O}_{3}$ measurements collected over the equatorial Atlantic and previous estimates of photochemical $\mathrm{O}_{3}$ production rates in $\mathrm{BB}$ plumes transported over the southern Atlantic Ocean. Enhanced $\mathrm{O}_{3}$ layers were observed over the Atlantic Ocean at equatorial latitudes by Jenkins et al. (2008). $\mathrm{O}_{3}$ concentrations between 70 to $100 \mathrm{ppbv}$ were measured in June 2006 mainly between 4 and $10 \mathrm{~km}$. Below $4 \mathrm{~km}$, plumes were not very pronounced with $\mathrm{O}_{3}$ concentrations generally lower than 60 ppbv. $\mathrm{O}_{3}$ concentrations between 80 and 90 ppbv between 3 and $12 \mathrm{~km}$ have also been observed at Ascension island $\left(7.90^{\circ} \mathrm{S}, 14.40^{\circ} \mathrm{W}\right)$ which is at lower latitudes than the case studied here (Thompson et al., 1996a). Our estimated $\mathrm{O}_{3}$ concentrations in the model runs including mixing over the Atlantic are in the same range of concentrations (80$100 \mathrm{ppbv}$ ), and also predict lower concentrations at lower altitude (71-80 ppbv). Jenkins et al. (2008) mainly observed layers with enhanced $\mathrm{O}_{3}$ at higher altitudes in June 2006 than suggested by our results for August 2006. Thouret et al. (2009) also showed that enhanced layers were observed over West Africa at higher altitude in June than in August during 2005 and 2006.

As highlighted in Sect. 1, previous studies estimating photochemical $\mathrm{O}_{3}$ production in $\mathrm{BB}$ plumes during transport downwind from South African $\mathrm{BB}$ regions showed $\mathrm{O}_{3}$ net production close to the emissions and weak net $\mathrm{O}_{3}$ destruction over the Atlantic (Mauzerall et al., 1998; Chatfield et al., 1996). In Mauzerall et al. (1998) the plume stayed above $4 \mathrm{~km}$ and in Chatfield et al. (1996) plumes were simulated between $3-6 \mathrm{~km}$. Other studies based on measurements made over the Atlantic (and not over the continent as in Mauzerall et al., 1998) estimates net $\mathrm{O}_{3}$ production rates between 1-4 ppbv/day in the mid-troposphere (Jacob et al., 1996; Thompson et al., 1996a). This production was attributed to BB by Thompson et al. (1996a) and to both BB and lightning by Jacob et al. (1996). This latter also calculated net $\mathrm{O}_{3}$ destruction ( $-0.7 \mathrm{ppbv} /$ day) below $4 \mathrm{~km}$.

When mixing is taken into account, we calculate a 10 day average $\mathrm{NPO}_{3}$ around $2.8 \mathrm{ppbv} /$ day above $4 \mathrm{~km}$ over the Atlantic and as high as $5 \mathrm{ppbv/day}$ during the first 4 days of transport downwind from West Africa. These results suggest that this aged plume, which is already 16 days old at the beginning of the simulation, is still very photochemically active. Previous studies focused on younger plumes and did not take into account the impact of aerosols, which as we have shown may lead to a delay in the peak $\mathrm{O}_{3}$ production. This effect could be particularly strong close to the fire emissions where aerosol optical depths are high and may partly explain the differences between our estimate and those from Mauzerall et al. (1998); Chatfield et al. (1996).

Following Thouret et al. (2009), $\mathrm{O}_{3}$ enhancements in the free troposphere over West Africa are observed during 40\% of the time in JJA 2005 and 2006 with an even higher occurrence in August 2006 (6 soundings over 7 show an $\mathrm{O}_{3}$ enhancement). They suggested that these layers have BB origins. The BOLAM model results discussed earlier confirmed that MT plumes over West Africa are transported over the south Atlantic. Therefore, it can be estimated that the midtroposphere over the equatorial South Atlantic is often impacted by BB air masses in JJA. With a mean $\mathrm{O}_{3}$ production rate of $2.6 \mathrm{ppbv} / \mathrm{day}$ at $4 \mathrm{~km}$ over the ocean, pollutant plumes from $\mathrm{BB}$ regions are likely to have a significant impact on $\mathrm{O}_{3}$ concentrations in the South Atlantic mid-troposphere. Simulated Atlantic $\mathrm{O}_{3}$ concentrations are on the same level than measured in $\mathrm{O}_{3}$ plumes suggesting that $\mathrm{O}_{3}$ enhancements in the South Atlantic mid-troposphere may be mainly explained by $\mathrm{BB}$ sources. However a more thorough study with a chemistry-transport model that can correctly simulate BB transport and take into account aerosol impacts on photolysis rates as well as lightning $\mathrm{NO}_{\mathrm{x}}$ is needed to better evaluate the contribution of $\mathrm{BB}$ emissions to the $\mathrm{O}_{3}$ budget in this region.

\subsection{Chemical fate of the UT plume}

\subsubsection{Model set-up}

For the UT plume, two runs were performed with chemistryonly (Run-CHEM) and chemistry plus mixing (Run-MIX) along the trajectory highlighted in bold in Fig. 8. No simulation including aerosol impact on photolysis rates were performed because a) the aircraft only measured part of the plume during the dive making it difficult to estimate the real vertical dimension of the plume and its AOD, and b) aerosol concentrations were lower than for the MT plume possibly due to a less polluted UT plume or washout so any aerosol impacts are likely to have been smaller. Fewer trace gases 
measurements were made by the M55 on 13 August which can be used to initialize the plume, namely $\mathrm{O}_{3}, \mathrm{NO}_{\mathrm{y}}, \mathrm{NO}$, and $\mathrm{CO}_{2}$ (see Fig. 3) making it necessary to estimate other species (VOCs, CO, missing $\mathrm{NO}_{\mathrm{y}}$ components). This means that the results presented here are not as well constrained as the MT case. Nevertheless, the model results can be used to provide an initial estimate of $\mathrm{NPO}_{3}$ in the UT from a $\mathrm{BB}$ plume.

In order to estimate the missing values, measurements from the MT plumes sampled by the DF- 20 and B- 146 were used. Assuming plumes underwent the same chemical and physical transformations during transport from BB emission region, the fraction $\frac{\Delta \text { Species }}{\Delta \mathrm{CO}_{2}}$ (where $\Delta$ is the difference between concentration in the plume and the background) should be approximately conserved between MT and UT $\left(\left(\frac{\Delta \text { Species }}{\Delta \mathrm{CO}_{2}}\right)_{\mathrm{UT}}=\left(\frac{\Delta \text { Species }}{\Delta \mathrm{CO}_{2}}\right)_{\mathrm{MT}}\right)$. This ratio is not modified by dilution or mixing since both species are affected to the same degree. According to Sect. 3, the plumes have approximately the same age so the level of oxidation in both plumes may not have been very different leading to small differences in $\mathrm{CO}$ and VOC lifetimes. By using measured $\left(\frac{\Delta \mathrm{CO}}{\Delta \mathrm{CO}_{2}}\right)_{\mathrm{MT}}$ and $\left(\frac{\Delta \mathrm{VOC}}{\Delta \mathrm{CO}_{2}}\right)_{\mathrm{MT}}$ combined with $\Delta \mathrm{CO}_{2}$ measured in the UT to obtain a UT $\triangle \mathrm{CO}$ and $\triangle \mathrm{VOC}, \mathrm{CO}$ and VOC concentrations in the UT plume were derived. Background concentrations were estimated from background concentrations measured during the campaign by the $\mathrm{M} 55$ for $\mathrm{CO}, \mathrm{CO}_{2}, \mathrm{NO}$, $\mathrm{NO}_{\mathrm{y}}, \mathrm{O}_{3}$ and taken from Jacob et al. (1996) for VOCs and $\mathrm{NO}_{\mathrm{y}}$ partitioning. The latter concentrations are typical values of tropical UT air masses (TRACE-A measurements over the south Atlantic)

On the other hand, $\frac{\Delta \mathrm{NO}_{\mathrm{y}}}{\Delta \mathrm{CO}_{2}}$ (measured both in the UT and the MT) is not conserved between plumes and this ratio in the MT plume is much higher than the UT plume (500 pptv/ppmv versus $25 \mathrm{pptv} / \mathrm{ppmv}$ ). This is most probably due to the fact that the UT air mass passed through a convective system with likely loss of $\mathrm{HNO}_{3}$ (and other soluble gases and aerosols) by washout. Removal of $\mathrm{HNO}_{3}$ by precipitation would also explain the high $\frac{\Delta \mathrm{NO}}{\Delta \mathrm{NO}_{2}}$ measured in the UT plume compared to the MT plume (due to loss of $\mathrm{NO}_{\mathrm{y}}$ ). Another phenomenon which could explain the high $\frac{\Delta \mathrm{NO}}{\Delta \mathrm{NO}_{2}}$ is lightning emissions of $\mathrm{NO}$, but it does not explain the low UT $\frac{\Delta \mathrm{NO}_{\mathrm{y}}}{\Delta \mathrm{CO}_{2}}$. Moreover NO in the UT plume is only slightly above mean NO measured by the M55 at that altitude during the campaign and a stronger NO signal would be expected if there had been recent lightning emissions. Therefore $\mathrm{LiNO}_{\mathrm{x}}$ influence on the UT plume studied here cannot be completely excluded but it is unlikely. Finally, in order to estimate $\mathrm{NO}_{\mathrm{y}}$ partitioning in the UT plume, $\frac{\Delta \mathrm{PAN}}{\Delta \mathrm{CO}_{2}}$ in the MT plume was used to derive UT PAN concentrations, $\mathrm{NO}_{2}$ concentrations were estimated using modelled $\mathrm{NO}_{2}$ :NO ratios at steady state, and the rest of measured $\mathrm{NO}_{\mathrm{y}}\left(\mathrm{NO}_{\mathrm{y}}-\right.$ $\mathrm{PAN}-\mathrm{NO}-\mathrm{NO}_{2}$ ) was attributed to $\mathrm{HNO}_{3}$. All measured
Table 2. Mean concentrations and standard deviations (in brackets) measured in the UT plume by the M55 aircraft. Concentrations used to initialised the box model calculation are given in the second column (see text for details). Background concentrations are taken from Jacob et al. (1996) (8-12 km).

\begin{tabular}{lrrr}
\hline & M55 & Initialisation & $\begin{array}{r}\text { background } \\
\text { concentrations }\end{array}$ \\
\hline $\mathrm{CO}$ (ppbv) & & 175 & 75 \\
$\mathrm{O}_{3}$ (ppbv) & $60(7)$ & 60 & 50 \\
$\mathrm{NO}$ (pptv) & $220(53)$ & 220 & 150 \\
$\mathrm{NO}_{2}$ (pptv) & & 200 & 10 \\
$\mathrm{PAN}^{\text {(pptv) }}$ & 330 & 223 \\
$\mathrm{HNO}_{3}$ (pptv) & & 70 & 59 \\
$\mathrm{NO}_{\mathrm{y}}$ & & \\
$\mathrm{C}_{2} \mathrm{H}_{4}$ (pptv) & 820 & 6 & 9 \\
$\mathrm{C}_{2} \mathrm{H}_{6}$ (pptv) & & 1000 & 670 \\
$\mathrm{C}_{2} \mathrm{H}_{2}$ (pptv) & & 190 & 110 \\
$\mathrm{C}_{3} \mathrm{H}_{6}$ (pptv) & & 10 & 4 \\
$\mathrm{C}_{4} \mathrm{H}_{1}$ (pptv) & & 1 & \\
$\mathrm{C}_{5} \mathrm{H}_{1}$ (pptv) & 100 & 15 \\
$\mathrm{C}_{6} \mathrm{H}_{6}$ (pptv) & & 3 & 2 \\
$\mathrm{C}_{7} \mathrm{H}_{8}$ (pptv) & & 400 & 40 \\
Formaldehyde (pptv) & & 1070 & 650 \\
$\mathrm{Acetone}_{\text {(pptv) }}$ & & & 376 \\
$\mathrm{CO}_{2}$ (ppmv) & 380 & & \\
\hline
\end{tabular}

and estimated values used to initialise the runs are reported Table 2.

In order to evaluate the mixing time to background for the UT plume, we used the BOLAM tracer results at $200 \mathrm{hPa}$ where, as mentioned previously, 32 daily tracers were used to represent the day to day transport of $\mathrm{CO}$ BB emissions. Three days were selected when there was injection of tracer at $200 \mathrm{hPa}$ over eastern/central Africa followed by decay and no new injection for several days afterwards. Using the hypothesis of an exponential decrease in the concentration toward a background value, a mixing time of 6 to 9 days was calculated using the linear regression of the logarithm of the maximum tracer concentration in the centre of the uplifted (model) plume as a function of time. Therefore, in Run-MIX we estimated a mixing timescale of 7 days.

\subsubsection{Results}

Results for RUN-CHEM are shown Fig. 13. As shown in Sect. 3, the UT plume is more diluted than the MT plume, and therefore $\mathrm{O}_{3}$ precursor concentrations are lower. However, $\mathrm{NPO}_{3}$ is only slightly smaller with a mean value over 10 days of $1.4 \mathrm{ppbv} /$ day compared to $1.6 \mathrm{ppbv} /$ day for the MT plume (chemistry only). In fact both photochemical production and destruction of $\mathrm{O}_{3}$ are smaller than in the MT plume (about only $10 \%$ of the MT values). Simulated $\mathrm{O}_{3}$ concentrations after 10 days are about $72 \mathrm{ppbv}$ in this chemistry only run. Since there are uncertainties in the initial concentrations used, especially for the VOCs, we performed a 

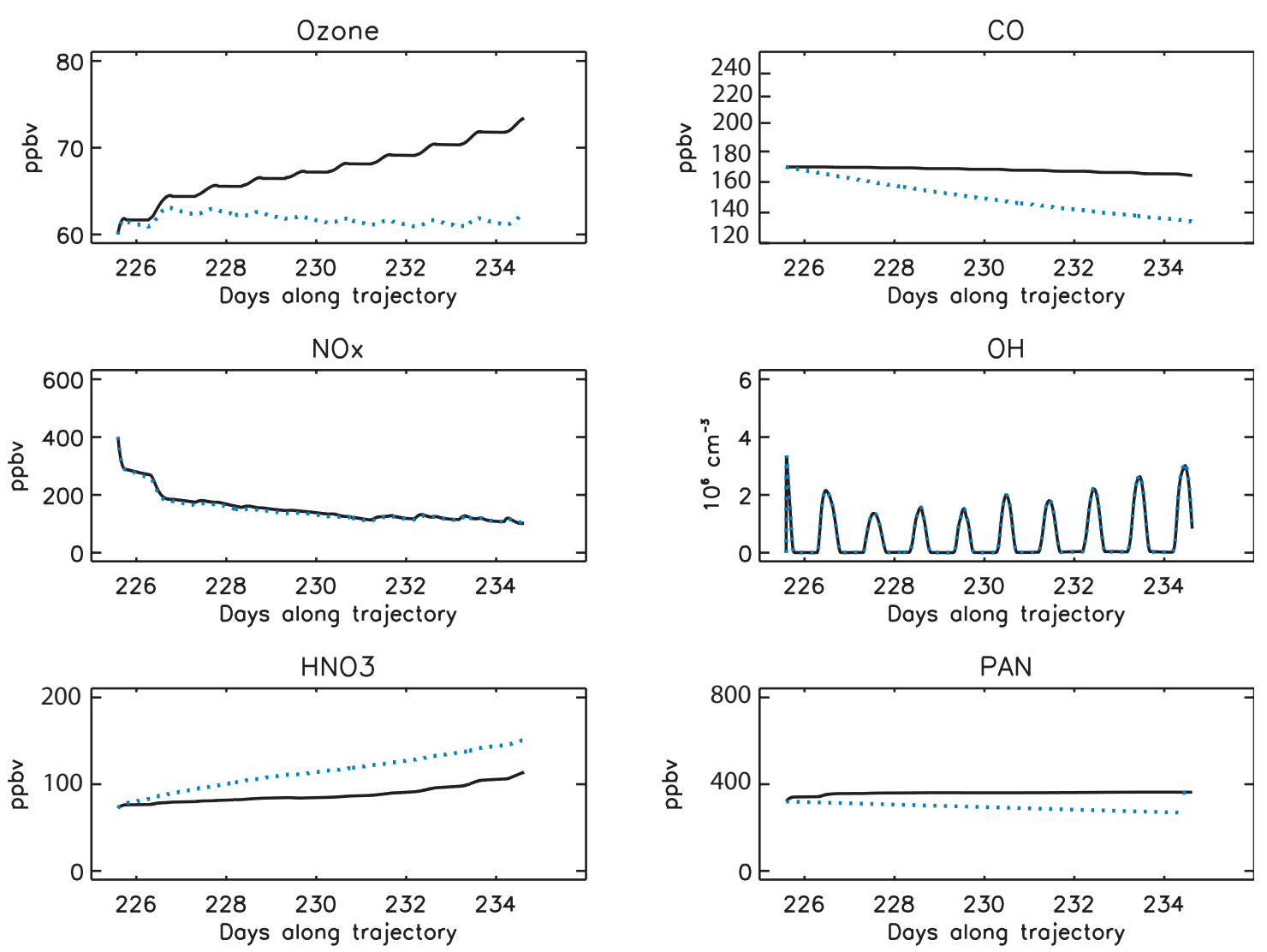

Fig. 13. 10 days simulated concentrations in the UT plume in the case RUN-CHEM (black line) and RUN-MIXING (blue lines).

sensitivity test where the initial VOC concentrations were doubled. $\mathrm{NPO}_{3}$ changes by only $10 \%$ whereas doubling $\mathrm{NO}_{\mathrm{x}}$ concentrations induces a $\mathrm{NPO}_{3}$ increase of $40 \%$. These results show that the UT plume is $\mathrm{NO}_{\mathrm{x}}$ limited, and therefore $\mathrm{NPO}_{3}$ not very sensitive to initial VOC concentrations. The $\mathrm{NO}_{\mathrm{x}}$ are better constrained by the measurements.

Inclusion of mixing leads to decreases in $\mathrm{O}_{3}$ concentrations to around $60 \mathrm{ppbv}$ whereas $\mathrm{CO}$ concentrations decrease by about $35 \mathrm{ppbv}$. Mean $\mathrm{NPO}_{3}$ only slightly decreases to $1.3 \mathrm{ppbv} /$ day resulting in the maintenance of $\mathrm{O}_{3}$ concentrations despite mixing with lower background concentrations. The mean $\mathrm{NPO}_{3}$ for the UT plume with mixing is about half that for the MT plume.

Sensitivity runs using different trajectories only showed small differences (not shown).

\subsubsection{Comparison with previous studies}

Our results present, as far as we know, some of the first estimates of in-situ $\mathrm{NPO}_{3}$ in UT BB plumes based on analysis of data. Other studies estimated $\mathrm{O}_{3}$ budget (without sources differentiation) over the South Atlantic using global models (Moxim and Levy, 2000) or measurements (Jacob et al., 1996). They estimated net $\mathrm{O}_{3}$ production rates of 1.5$2.1 \mathrm{ppbv/day}$ in the UT over the south Atlantic. This number is higher than our estimates of $\mathrm{NPO}_{3}$. Also, $\mathrm{O}_{3}$ plumes observed in the South Atlantic UT generally exhibit $\mathrm{O}_{3}$ concentrations between $80-100$ ppbv when our simulation suggest 60 ppbv. However, the M55 may only have sampled the upper part of the plume during the dive over the Gulf of Guinea (see Fig. 1), and, as such, may not have sampled the highest concentrations. A less diluted plume would exhibit stronger $\mathrm{O}_{3}$ production. MOZAIC data collected at $11 \mathrm{~km}$ during this period shows $\mathrm{CO}$ concentrations up to $240 \mathrm{ppbv}$ which is higher than CO simulated in the UT plume (170 ppbv) in the case studied here. Therefore it is difficult to conclude on $\mathrm{BB}$ contribution to $\mathrm{O}_{3}$ maximum on the UT. As our dynamic model BOLAM suggest sporadic transport in the UT and given the calculated $\mathrm{NPO}_{3}$ in the UT plume it is unlikely that BB sources dominate this UT maximum but they can be an important contribution in some cases and need to be taken into account in global model simulations together with the important and more continuous source of enhanced $\mathrm{O}_{3}$ from lightning $\mathrm{NO}_{\mathrm{x}}$ emissions. 


\section{Conclusions}

In this study we examined the origin and downwind $\mathrm{O}_{3}$ production potential of pollutant plumes observed in the mid and upper troposphere over the southern coast of West Africa during August 2006 summer monsoon. Analysis of results from the BOLAM mesoscale model, including biomass burning $\mathrm{CO}$ tracers confirmed that the likely origin of the plumes was from biomass burning emission regions over central Africa. Model results showed BB pollutants confined over central Africa for between 12 days before being transported to the measurement region 4 days (MT plume) and 2 days (UT plume) later. According to the model both plumes are about 14 days old when measured over West Africa. The plumes observed in the mid troposphere had significantly higher pollutant concentrations than the plume observed in the upper troposphere. The mesocale model reproduces these differences and shows two different pathways for the plumes at the different altitudes: transport to the north-east of the fire region, moist convective uplift and transport to West Africa driven by the tropical easterly jet for the upper tropospheric plume; north-west transport from the emission region to the Gulf of Guinea for the middle tropospheric plume. The UT:MT ratio of tracer concentrations at $600 \mathrm{hPa}$ and $250 \mathrm{hPa}$ was estimated to around 0.42 for the period 14-15 August in the region of the measurements which agrees well with the ratio derived from observed $\mathrm{CO}_{2}$ enhancements in the plumes. Lower pollutant concentrations in the UT are mainly due to more dilution with cleaner air masses during upward transport. The same UT:MT fraction was evaluated over a larger period: $1-15$ August and a mean value of 0.6 was simulated showing that even if injection of pollutants into the UT over West Africa is less frequent and plumes more diluted, it is significant, at least in the studied period (August 2006). This fraction is higher than previously suggested (Mari et al., 2008).

$\mathrm{Net}_{3}$ production downwind from West Africa was evaluated using a photochemical trajectory model initialized with the measurements. The mid-tropospheric plume was transported over the equatorial south Atlantic between 1.5 and $6 \mathrm{~km}$. Simulations show that transport altitude strongly influences the resulting net $\mathrm{O}_{3}$ production in the plume. Whereas below $2 \mathrm{~km}$ a net $\mathrm{O}_{3}$ destruction was simulated, above $3 \mathrm{~km}$, the plume produced $\mathrm{O}_{3}$ with a mean rate of $2.6 \mathrm{ppbv} /$ day over 10 days. During the first few days, this production even reached $7 \mathrm{ppbv/day}$. Our estimates of net $\mathrm{O}_{3}$ production rates are higher than previously reported for aged BB plumes (1626 days old here). We show that this net production is not directly due to transport of $\mathrm{NO}_{2}$ but to $\mathrm{NO}_{2}$ recycling by $\mathrm{NO}_{2}$ reservoir species: PAN and $\mathrm{HNO}_{3}$, which contribute equally. Model runs including the impact of aerosols on photolysis rates show that their main effect is to delay the maximum in $\mathrm{O}_{3}$ downwind. This process may explain why previous studies estimated lower $\mathrm{NPO}_{3}$ compared to this study. Given the possibility that aged BB plumes transported over the Atlantic could be still very photochemically active, it is likely that this source is making a significant contribution (more than previously estimated) to $\mathrm{O}_{3}$ levels in the MT. According to simulated occurrence of such transport, $\mathrm{BB}$ may even be the main source for $\mathrm{O}_{3}$ enhancement in the equatorial south Atlantic MT, at least in August 2006. Slower net $\mathrm{O}_{3}$ production rates and lower $\mathrm{O}_{3}$ concentrations were simulated in the UT plume together with lower occurrence of transport.

In this study, we have focused on estimating in-situ $\mathrm{O}_{3}$ production rates in a plume of $\mathrm{BB}$ origin. In order to understand the contribution from different $\mathrm{O}_{3}$ sources to the $\mathrm{O}_{3}$ maximum observed over the southern Atlantic it will be necessary to perform similar calculations for other important sources, and especially plumes influenced by $\mathrm{LiNO}_{\mathrm{x}}$. Indeed, even if simulated plume may not be representative of the more polluted BB plume in the UT, it seems that BB plumes are not the dominant source of $\mathrm{O}_{3}$ production in the UT. As suggested in previous studies $\mathrm{LiNO}_{\mathrm{x}}$ is probably more important to explain the UT maximum but this study show that BB may dominate the MT maximum. It would be interesting to estimate the importance of the MT maximum versus the UT maximum over the equatorial south Atlantic. According to Thouret et al. (2009) it may depend on the month of the year (with a maximum MT signal in August, equivalent to the UT signal). Simulations with a global chemistry model including aerosol impacts would be necessary to precisely and quantitatively estimate $\mathrm{BB}$ contribution to the $\mathrm{O}_{3}$ maximum.

Acknowledgements. Based on a French initiative, AMMA was built by an international scientific group and is currently funded by a large number of agencies, especially from France, the United Kingdom, the United States, and Africa. It has been a beneficiary of a major financial contribution from the European Community Sixth Framework Programme (AMMA-EU). Detailed information on scientific coordination and funding is available on the AMMA International website at http://www.amma-international.org/rubrique. php3?id_rubrique $=1$.

The DF-20 campaign was funded partly through AMMA-EU. The M55-Geophysica campaign was funded by AMMA-EU, EC Integrated Project SCOUT-O 3 (505390-GOCE-CT-2004), CNRSINSU, CNES, EUFAR and the M55 aircraft consortium. We would like to thank all the scientists aircraft operators as well as local scientists and representatives in Burkina Faso for their help and support during the planning and execution of the Ouagadougou campaign. We also acknowledge support from the AMMA Operations Centre in Niamey, Niger.

The B-146 campaign was funded in part by AMMA-EU and also through a NERC AMMA-UK consortium grant. We also acknowledge B-146 data provided by the Facility for Airborne Atmospheric Measurements (FAAM) and the British Atmospheric Data Centre (BADC). E. Real acknowledges funding from the AMMA-EU.

Edited by: C. Reeves 


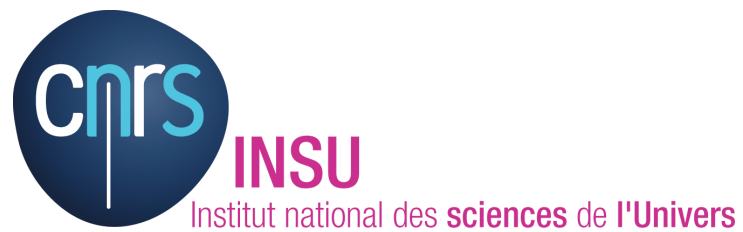

The publication of this article is financed by CNRS-INSU.

\section{References}

Ancellet, G., Leclair de Bellevue, J., Mari, C., Nedelec, P., Kukui, A., Borbon, A., and Perros, P.: Effects of regional-scale and convective transports on tropospheric ozone chemistry revealed by aircraft observations during the wet season of the AMMA campaign, Atmos. Chem. Phys., 9, 383-411, 2009, http://www.atmos-chem-phys.net/9/383/2009/.

Andrés-Hernández, M. D., Kartal, D., Reichert, L., Burrows, J. P., Meyer Arnek, J., Lichtenstern, M., Stock, P., and Schlager, H.: Peroxy radical observations over West Africa during AMMA 2006: photochemical activity in the outflow of convective systems, Atmos. Chem. Phys., 9, 3681-3695, 2009, http://www.atmos-chem-phys.net/9/3681/2009/.

Borrmann, S., Kunkel, D., Weigel, R., Minikin, A., Deshler, T., Wilson, J. C., Curtius, J., Shur, G. N., Belyaev, G. V., Law, K. S., and Cairo, F.: Aerosols in the tropical and subtropical UT/LS: insitu measurements of submicron particle abundance and volatility, Atmos. Chem. Phys. Discuss., 9, 24587-24628, 2009,

http://www.atmos-chem-phys-discuss.net/9/24587/2009/.

Burpee, R. W.: The origin and structure of easterly waves in the lower troposphere of North Africa, J. Atmos. Sci., 29, 77-90, 1972.

Buzzi, A. and Foschini, L.: Mesoscale meteorological features associated with heavy precipitation in the southern Alpine region., Meteorol. Atmos. Phys., 72, 131-146, 2000.

Cairo, F., Pommereau, J. P., Law, K. S., Schlager, H., Garnier, A., Fierli, F., Ern, M., Streibel, M., Arabas, S., Borrmann, S., Berthelier, J. J., Blom, C., Christensen, T., D'Amato, F., Di Donfrancesco, G., Deshler, T., Diedhiou, A., Durry, G., Engelsen, O., Goutail, F., Harris, N. R. P., Kerstel, E. R. T., Khaykin, S., Konopka, P., Kylling, A., Larsen, N., Lebel, T., Liu, X., MacKenzie, A. R., Nielsen, J., Oulanowski, A., Parker, D. J., Pelon, J., Polcher, J., Pyle, J. A., Ravegnani, F., Rivire, E. D., Robinson, A. D., Röckmann, T., Schiller, C., Simões, F., Stefanutti, L., Stroh, F., Some, L., Siegmund, P., Sitnikov, N., Vernier, J. P., Volk, C. M., Voigt, C., von Hobe, M., Viciani, S., and Yushkov, V.: An introduction to the SCOUT-AMMA stratospheric aircraft, balloons and sondes campaign in West Africa, August 2006: rationale and roadmap, Atmos. Chem. Phys., 10, 2237-2256, 2010, http://www.atmos-chem-phys.net/10/2237/2010/.

Chatfield, R., Vastano, J. A., Singh, H. B., and G.Sachse: A general model of how fire emissions and chemistry produce African/oceanic plumes (O3, CO, PAN, smoke) in TRACE-A, J. Geophys. Res., 101, 24279-24306, 1996.

Crutzen, P. J. and Andreae, M. O.: Biomass burning in the tropics: Impact on atmospheric chemistry and biogeochemical cycles, Science, 250, 1669-1678, 1990.
Evans, M. J., Shallcross, D. E., Law, K. S., Wild, J. O. F., Simmonds, P. G., Spain, T. G., Berrisford, P., Methven, J., Lewis, A. C., McQuaid, J. B., Pillinge, M. J., Bandyf, B. J., Penkett, S. A., and Pyle, J. A.: Evaluation of a Lagrangian box model using field measurements from EASE (Eastern Atlantic Summer Experiment) 1996, Atmos. Environ., 34, 3843-3863, 2000.

Fueglistaler, S., Dessler, A. E., Dunkerton, T. J., Folkins, I., Fu, Q., and Mote, P. W.: Tropical tropopause layer, Rev. Geophys., 47, RG1004, doi:8755-1209/09/2008RG000267, 2009.

Haywood, J. M., Osborne, S. O., Francis, P. N., Keil, A., Formenti, P., Andreae, M. O., and Kaye, P. H.: The mean physical and optical properties of regional haze dominated by biomass burning aerosol measured from the C-130 aircraft during SAFARI 2000 , J. Geophys. Res., 108, 8473, doi:10.1029/2002JD002226, 2003.

Heald, C. L., Jacob, D. J., Fiore, A. M., Emmons, L. K., Gille, J. C., Deeter, M. N., Warner, J., Edwards, D. P., Crawford, J. H., Hamlin, A. J., Sachse, G. W., Browell, E. V., Avery, M. A., Vay, S. A., Westberg, D. J., Blake, D. R., Hanwant, B., Sandholm, S. T., Talbot, R. W., and Fuelberg, H. E.: Asian outflow and transPacific transport of carbon monoxide and ozone pollution: An integrated satellite, aircraft, and model perspective., J. Geophys. Res., 108, 4804, doi:10.1029/2003JD003 507, 2004.

Jacob, D. J., Heikes, B. G., Fan, S.-M., Logan, J. A., Mauzerall, D. L., Bradshaw, J. D., Singh, H. B., Gregory, G. L., Talbot, R. W., Blake, D. R., W., G., and Sachse: Origin of ozone and NOx in the tropical troposphere: A photochemical analysis of aircraft observations over the South Atlantic basin, J. Geophys. Res., 101, 24235-24250, 1996.

Janicot, S., Thorncroft, C. D., Ali, A., Asencio, N., Berry, G., Bock, O., Bourles, B., Caniaux, G., Chauvin, F., Deme, A., Kergoat, L., Lafore, J.-P., Lavaysse, C., Lebel, T., Marticorena, B., Mounier, F., Nedelec, P., Redelsperger, J.-L., Ravegnani, F., Reeves, C E., Roca, R., de Rosnay, P., Schlager, H., Sultan, B., Tomasini, M., Ulanovsky, A., and ACMAD forecasters team, : Large-scale overview of the summer monsoon over West Africa during the AMMA field experiment in 2006, Ann. Geophys., 26, 25692595, 2008, http://www.ann-geophys.net/26/2569/2008/.

Jenkins, G. S. and Ryu, J.-H.: Space-borne observations link the tropical atlantic ozone maximum and paradox to lightning, Atmos. Chem. Phys., 4, 361-375, 2004a, http://www.atmos-chem-phys.net/4/361/2004/.

Jenkins, G. S. and Ryu, J.-H.: Linking horizontal and vertical transports of biomass fire emissionsto the tropical Atlantic ozone paradox during the Northern Hemisphere winter season: climatology, Atmos. Chem. Phys., 4, 449-469, 2004b, http://www.atmos-chem-phys.net/4/449/2004/.

Jenkins, G. S., Camara, M., and Ndiaye, S. A.: Observational evidence of enhanced middle/upper tropospheric ozone via convective processes over the equatorial tropical Atlantic during the summer of 2006, Geophys. Res. Lett., 35, L12806, doi:10.1029/2008GL033 954, 2008.

Kain, J.: The KainFritsch convective parameterization: An update., J. Appl. Meteorol., 43, 170-181, 2004

Law, K. S.: Air mass origins influencing TTL chemical composition over West Africa during the 2006 summer monsoon, Atmos. Chem. Phys. Discuss., in preparation, 2010. 
Liousse, C.: African Aerosols Modeling during the EOP-AMMA campaign with updated biomass burning emission inventories, Atmos. Chem. Phys. Discuss., in preparation, 2010.

Malguzzi, P., Grossi, G., Buzzi, A., Ranzi, R., and Buizza, R.: The 1966 century flood in Italy: A meteorological and hydrological revisitation., J. Geophys. Res., 111, D24106, doi:10.1029/2006JD007111, 2006.

Mari, C. H., Cailley, G., Corre, L., Saunois, M., Attié, J. L., Thouret, V., and Stohl, A.: Tracing biomass burning plumes from the Southern Hemisphere during the AMMA 2006 wet season experiment, Atmos. Chem. Phys., 8, 3951-3961, 2008, http://www.atmos-chem-phys.net/8/3951/2008/.

Mauzerall, D. L., Logan, J. A., Jacob, D. J., Anderson, B. E., Blake, D. R., Bradshaw, J. D., Haikes, B., Sachse, G. W., Singh, H., and Talbot, B.: Photochemistry in biomass burning plumes and implications for tropospheric ozone over the tropical South Atlantic, J. Geophys. Res., 103, 8401-8423, 1998.

Mishchenko, M. I., Goegdzhayev, I., Cairns, B., Rossow, W. B., and Lacis, A. A.: Aerosol retrievals over the ocean by use of channels 1 and 2 AVHRR data: sensitivity analysis and preliminary results, Appl. Optics, 38, 7325-7341, 1999.

Moxim, W. J. and Levy, H.: A model analysis of the tropical South Atlantic Ocean tropospheric ozone maximum: The interaction of transport and chemistry, J. Geophys. Res., 105, 17393-17416, 2000 .

Neuman, J. A., Parrish, D. D., Trainer, M., Ryerson, T. B., Holloway, J. S., Nowak, J. B., Swanson, A., Flocke, F., Roberts, J. M., Brown, S. S., Stark, H., Sommariva, R., Stohl, A., Peltier, R., Weber, R., Wollny, A. G., Sueper, D. T., Hubler, G., and Fehsenfeld, F. C.: Reactive nitrogen transport and photochemistry in urban plumes over the North Atlantic Ocean, J. Geophys. Res., 111, D23S54, doi:10.1029/2005JD007 010, 2006.

Nicholson, S. E. and Grist, J.: The seasonal evolution of the atmospheric circulation over West Africa and Equatorial Africa, J. Clim, 16, 1013-1030, 2003.

Park, S., Jiménez, R., Daube, B. C., Pfister, L., Conway, T. J., Gottlieb, E. W., Chow, V. Y., Curran, D. J., Matross, D. M., Bright, A., Atlas, E. L., Bui, T. P., Gao, R.-S., Twohy, C. H., and Wofsy, S. C.: The $\mathrm{CO}_{2}$ tracer clock for the Tropical Tropopause Layer, Atmos. Chem. Phys., 7, 3989-4000, 2007, http://www.atmos-chem-phys.net/7/3989/2007/.

Proceedings of the Fourteenth International TOVS Study Conference Conference; Beijing, China, RTTOV-8 the latest update to the RTTOV model., 21-31 May 2005, 2005.

Real, E., Law, K. S., Wienzierl, B., Fiebig, M., Petzold, A., Wild, O., Methven, J., Arnold, S., Stohl, A., Huntrieser, H., Roiger, A., Schlager, H., Stewart, D., Avery, M., Sachse, G., Browell, E., Ferrare, R., and Blake, D.: Processes influencing ozone levels in Alaskan forest fires plumes during long-range transport over the North Atlantic, J. Geophys. Res., 112, D10S41, doi:10.1029/2006JD007 576, 2007.

Real, E., Law, K. S., Schlager, H., Roiger, A., Huntrieser, H., Methven, J., Cain, M., Holloway, J., Neuman, J. A., Ryerson, T., Flocke, F., de Gouw, J., Atlas, E., Donnelly, S., and Parrish, D.: Lagrangian analysis of low altitude anthropogenic plume processing across the North Atlantic, Atmos. Chem. Phys., 8, 77377754, 2008,

http://www.atmos-chem-phys.net/8/7737/2008/.
Reeves, C. E., Formenti, P., Afif, C., Ancellet, G., Attie, J.-L., Bechara, J., Borbon, A., Cairo, F., Coe, H., Crumeyrolle, S., Fierli, F., Flamant, C., Gomes, L., Hamburger, T., Lambert, C., Law, K. S., Mari, C., Matsuki, A., Methven, J., Mills, G. P., Minikin, A., Murphy, J. G., Nielsen, J. K., Oram, D. E., Parker, D. J., Richter, A., Schlager, H., Schwarzenboeck, A., and Thouret, V.: Chemical and aerosol characterisation of the troposphere over West Africa during the monsoon period as part of AMMA, Atmos. Chem. Phys. Discuss., 10, 7115-7183, 2010, http://www.atmos-chem-phys-discuss.net/10/7115/2010/.

Remer, L., Kaufman, Y. J., Tanre, D., Mattoo, S., Chu, D. A., Martins, J. V., Li, R. R., Ichoku, C., Levy, R. C., Kleidman, R. G., Eck, T. F., Vermote, E., and Holben, B. N.: The MODIS Aerosol Algorithm, Products, and Validation, J. Atmos. Sci., 62, 947973, 2005.

Sauvage, B., Thouret, V., Cammas, J.-P., Gheusi, F., Athier, G., and Nédélec, P.: Tropospheric ozone over Equatorial Africa: regional aspects from the MOZAIC data, Atmos. Chem. Phys., 5, 311335, 2005,

http://www.atmos-chem-phys.net/5/311/2005/.

Sauvage, B., Thouret, V., Thompson, A. M., Witte, J. C., Cammas, J.-P., Nedelec, P., and Athier, G.: Enhanced view of the tropical Atlantic ozone paradox and zonal wave one from the in situ MOZAIC and SHADOZ data, J. Geophys. Res., 11, 1301, doi:10.1029/2005JD00 624, 2006.

Sauvage, B., Martin, R. V., van Donkelaar, A., and Ziemke, J. R.: Quantification of the factors controlling tropical tropospheric ozone and the South Atlantic maximum, J. Geophys. Res., 112, 11309, doi:10.1029/2006JD008 008, 2007a.

Sauvage, B., Thouret, V., Cammas, J.-P., Brioude, J., Ndlec, P., and Mari, C.: Meridional ozone gradients in the African upper troposphere, Geophys. Res. Lett., 34, 3817, doi:10.1029/2006GL028 542, $2007 \mathrm{~b}$.

Stohl, A., Wotawa, G., Seibert, P., and Kromp-Kolb, H.: Interpolation errors in wind fields as a funcion of spatial and temporal resolution and their impact on different types of kinematic trajectories, J. Appl. Meteorol., 34, 2149-2165, 1995.

Tanre, D., Kaufman, Y., Herman, M., and Mattoo, S.: Remote sensing of aerosol properties over oceans using the MODIS sol EOS spectral radiances, J. Geophys. Res., 102, 16971-16988, 1997.

Thompson, A., Diab, R. D., Bodeker, G. E., Zunckel, M., Coetzee, G. J. R., Archer, C. B., McNamara, D. P., Pickering, K. E., Combrink, J., Fishman, J., and Nganga, D.: Ozone over southern Africa during SAFARI-92/TRACE A, J. Geophys. Res., 101, 23793-23807, 1996a.

Thompson, A. M., Pickering, K. E., McNamara, D. P., M. R. Schoeberl, R. D. H., Kim, J. H., Browell, E. V., Kirchhoff, V. W. J. H., and Nganga, D.: Where did tropospheric ozone over southern Africa and the tropical Atlantic come from in October 1992? Insights from TOMS, GTE/TRACE-A, and SAFARI-92, J. Geophys. Res., 101, 24251-24278, 1996 b.

Thouret, V., Saunois, M., Minga, A., Mariscal, A., Sauvage, B., Solete, A., Agbangla, D., Nédélec, P., Mari, C., Reeves, C. E., and Schlager, H.: An overview of two years of ozone radio soundings over Cotonou as part of AMMA, Atmos. Chem. Phys., 9, 6157-6174, 2009,

http://www.atmos-chem-phys.net/9/6157/2009/. 
Voigt, C., Schlager, H., Roiger, A., Stenke, A., de Reus, M., Borrmann, S., Jensen, E., Schiller, C., Konopka, P., and Sitnikov, N.: Detection of reactive nitrogen containing particles in the tropopause region - evidence for a tropical nitric acid trihydrate (NAT) belt, Atmos. Chem. Phys., 8, 7421-7430, 2008, http://www.atmos-chem-phys.net/8/7421/2008/.
Weller, R., Lilischkis, R., Schrems, O., Neuber, R., , and Wessel, S.: Vertical ozone distribution in the marine atmosphere over the central Atlantic Ocean ( $\left.56^{\circ} \mathrm{S}-50^{\circ} \mathrm{N}\right)$, J. Geophys. Res., 101, 1387-1400, 1996.

Wild, O., Zhu, X., and Prather, M. J.: Fast-J: Accurate Simulation of In- and Below-Cloud Photolysis in Tropopsheric Chemical Models, J. Atmos. Chem., 37, 245-282, 2000. 